\title{
Chapter 3 - Changes in soil ecosystem structure and functions due to soil contamination
}

\author{
Rui G. Morgado, Susana Loureiro and Maria Nazaret González-Alcaraz \\ Department of Biology \& CESAM, University of Aveiro, Portugal
}

\begin{abstract}
Soil ecosystems are nowadays exposed to several physical, chemical and biological stressors, which are directly or indirectly related to anthropogenic activities. This chapter covers how contaminants affect the soil ecosystem structure, changing soil functions and services. Soil ecosystem structure is constituted by dynamic interactive abiotic and biotic compartments, dependent on major key factors like water and light. By changing this balanced system, soil functions are also impaired as they are strictly dependent on this structure and biodiversity. Soil functions include carbon transformations, nutrient cycling, maintenance of the structure itself, and regulation of biological populations. Activities like mining, agriculture, forestry or waste disposal are often responsible for the unbalance of soil structure and functions, by jeopardizing majorly the functional biodiversity compartment of the ecosystem. Therefore, the provision of goods along with ecosystem services will be also affected. Valuing soil ecosystem services is a difficult task and often lacking at the policymaking level, as the costs of services losses can go unnoticed. Therefore new strategies should be implemented to bring the concepts of structure, functions, services and goods on board at the regulation level.
\end{abstract}

Key-words: soil organic matter, nutrient cycling, functional biodiversity, services and goods, soil pollution 


\section{Introduction}

Soil is a complex dynamic system constituted by biotic and abiotic components that represents the primary habitat and harbor of biological activity and diversity, supporting several ecosystem services. Soil formation depends on several factors such as parent material, topography, climate, biota and time. These factors will influence soil formation as well as the characteristics soil will have, influencing all its functions, services, and ability to produce goods.

Ecosystem services are defined as the benefits that people receive from nature, essential for the overall environmental health and human well-being (MA, 2005). The Millennium Ecosystem Assessment (MA) and the Common International Classification of Ecosystem Services (CICES) establish in a general way major categories of ecosystem services (MA, 2005; Haines-Young and Potschin, 2011): Provisioning, which includes the production of goods by ecosystems (e.g. food, water, fibers, or energy); Regulating, which includes the maintenance of several processes related to climate, water and air quality, pest and disease control, or pollination; Supporting, necessary for the performance of all other services such as soil formation, nutrient cycling, primary production, or habitat provision; Cultural, which includes non-material benefits like recreation, ecotourism, cultural heritage, or spiritual and religious values. Figure 1 shows the relationships between soil ecosystem services and functions. Ecosystem services, which are mainly based on soil goods and functions, can be valued quantitatively in monetary or non-monetary terms (Silvertown, 2015; Selck et al., 2017).

Soil ecosystem services depend on soil ecosystem structure (soil biotic and abiotic components and the interactions within and between them) and soil ecosystem functions (natural processes occurring in soil). In both cases, the soil, water and air compartments are interconnected and their quality and sustainability are dependent from each other. Soil ecosystem structure is responsible for the adaptations of individual organisms, but at the same time their role and function in soil change also the ecosystem structure. Biodiversity therefore rules soil structure and functions (Wall et al., 2012). Ecosystem services depend highly on soil biodiversity, accounting along with its trophic and behavioral interactions, in a temporal and spatial scale. 
The soil compartment often suffers several threats from direct or indirect anthropogenic sources. Agricultural and forestry practices, urbanization (e.g. waste disposal), mining and industrial activities are among the main causes of soil misuse and overexploitation. Contaminants in soil will only become hazardous when deleterious effects are perceived. In this way, when soil contamination affects the biota, all soil functions and services can potentially be changed; therefore soil pollution is an issue that has to be taken into account in risk assessment procedures. In addition, climate alterations induce also pressures on soil ecosystems, by altering the physical, chemical and structural composition of soil. Several soil functions can be jeopardized from these pressures, thus affecting the goods and services provided by soil ecosystems.

\section{Soil ecosystem structure}

\section{- Soil structure}

Soils are the central organizing element in terrestrial ecosystems, with a multitude of geochemical and ecological functions (Coleman and Whitman, 2005; Crawford et al., 2005; Wall et al., 2010). Soils' position, at the interface among the lithosphere, atmosphere, hydrosphere and biosphere, confers them a highly dynamic and multiphase character where multiple-sized aggregates are linked and stabilized within an intricate matrix of solid, liquid and gaseous components interacting at various scales (Parker, 2010; Lal, 2016).

Solid components include both inorganic and organic materials heterogeneously organized and creating a three-dimensional porous matrix with complex geometry (Crawford et al., 2005; Ritz, 2008). Soil particles do not create a continuous and compact mass, making possible life in soil. In fact, the volume formed by pores, chambers, channels and cracks provides a suitable environment for soil biota and the growth of plant roots. This pore space network also regulates the flux of gases and liquids within soil creating multiple amphibious environments, heterogeneously filled with soil solution and partly filled with soil gases, which are crucial for soil biota (Lavelle, 2012). Water composition and reactivity in soil pores depend on the properties of the incoming water along with the characteristics of the soil solid phase, the biota and 
the interface with the atmosphere. The soil solution is constituted by water and a wide variety of dissolved and suspended materials (organic, inorganic and organo-mineral) (Lavelle and Spain, 2001). Mobile elements sorbed on the soil solid phase diffuse to the liquid phase. Therefore, nutrients and contaminants become available to the majority of soil living organisms and plants when dissolved in soil pore water. Soil gaseous phase comprises $\mathrm{O}_{2}$ consumption and $\mathrm{CO}_{2}$ production during biological activities. When $\mathrm{O}_{2}$ in soil decreases, there is an exchange of $\mathrm{O}_{2}$ between the atmosphere and the soil due to a differential gradient, with $\mathrm{CO}_{2}$ flux occurring in the opposite direction. The relative humidity of soil atmosphere remains close to saturation, which is vital to most soil biota (Lavelle and Spain, 2001).

\section{- Soil biodiversity}

Soils are amongst the most species-rich ecosystems on Earth (Giller, 1996). Nowhere in nature is possible to find so many species and so densely packed as in soil ecosystems (Hågvar, 1998). Unfortunately, in spite of the huge effort made by soil ecologists in the last few decades to describe and understand soil communities, the taxonomic deficit for soil biodiversity is still one of the highest (Decaëns, 2010) and little is known about their structure and dynamics (Bardgett and van der Putten, 2014). Although the true extent of soil biodiversity remains relatively unknown, one aspect is already undisputable: soil biodiversity is key for the proper soil functioning and underpins all soil-based ecosystem services and goods (Barrios, 2007). Therefore, improving the knowledge about soil biodiversity is paramount to increase the ability to understand the mechanisms underlying soil health, effectively manage soil-based ecosystem services and predict future trends and scenarios for the Anthropocene (Bardgett and van der Putten, 2014).

Despite the significant bias towards the aboveground part of soil ecosystems, it is belowground where the greatest diversity is found (Wardle, 2006; Thiele-Bruhn et al., 2012). Belowground biodiversity is concentrated on the pore space (Lavelle, 2012). The pore space is a highly constraining and multiphase environment characterized by an overall low quality of resources and patchily distributed "hot spots" (Lavelle et al., 1994; Crawford et al., 2005). Having an increased surface area, but limited connectivity, these pore spaces create a multitude of dynamic microenvironments where local species 
are subject to low competitive exclusion, thereby promoting coexistence through resource partitioning (Decaëns et al., 2006). Within soils, the importance of competition as structuring force of small-sized biota is mostly restricted to fine scales, such as the aggregatusphere for microbial communities or the porosphere/rhizosphere for microfauna, where potential competitors might use the same space and available resources (Ettema and Wardle, 2002). A higher degree of connectivity would allow greater possibilities of exchanging genetic material, leading to higher homogeneity and less diversity (Lavelle, 2012). Soil communities are therefore hyperdiverse and extremely complex and encompass organisms from all major taxonomic groups (Wardle, 2006; Parker, 2010). Nevertheless, larger animals, with higher mobility, may be spatially structured at the plot level (Ettema and Wardle, 2002).

Soil organisms are normally classified based on their body width whose variation within soil communities spans several orders of magnitude (Barrios, 2007; Parker, 2010; Lavelle, 2012). The bulk of soil diversity is composed by microbiota such as bacteria, archaea and fungi, but it also comprises remarkable diversity of microfauna, mesofauna, macrofauna and even megafauna (e.g. mammals, reptiles) (Bardgett, 2002; Wurst et al., 2012; Orgiazzi et al., 2016). Besides, it also includes a huge variety of photosynthetic organisms such as lichens and plants with key roles in soil ecosystems structure (Orgiazzi et al., 2016). Soil microbiota contribute mainly to decomposition processes, favoring $\mathrm{C}$ and nutrient cycling, but also plays an important role in disease defeat and plant growth regulation (Wurst et al., 2012). These organisms play also important symbiotic interactions with plants, crucial in the plant root axis, improving nutrient uptake (e.g. helping $\mathrm{N}$ fixation) and/or regulating plant hormones (Wurst et al., 2012). Soil microfauna include organisms $<100 \mu \mathrm{m}$ (e.g. nematodes, protozoa, and rotifers). They feed on bacteria, fungi and algae, but they also present predator and saprophytic groups. By their activities they regulate i) nutrient cycling by improving the availability of nutrients to other species (e.g. through their faeces), ii) population size and activity of bacteria and fungi, and iii) the dispersion of crucial rhizosphere microbiota (Wurst et al., 2012). Their deleterious effects to plants are also known, when microfauna inhabit in more direct contact with roots, by feeding on those roots or changing plants defenses or hormones. Soil mesofauna $(100 \mu \mathrm{m}-2 \mathrm{~mm})$ main groups are Acari, Collembola, Tardigrada, Protura, Diplura, and Enchytraeidae. These organisms are mainly herbivores, bacterivores or fungivores. In some cases, they also feed on other soil 
organisms belonging to higher trophic levels. They live in close contact with the air and water present in soil and therefore are very dependent on soil aeration and moisture. These organisms contribute to nutrient cycling, pest and disease suppression, serve as food for other soil organisms, and participate in soil biota distribution (Wurst et al., 2012). Soil macrofauna $(>2 \mathrm{~mm})$ is the main responsible for litter fractionation and predation on other soil-dwelling organisms, often called "ecosystem engineers". Macroarthropods (e.g. isopods. spiders, insects) along with soft-bodied organisms (e.g. annelids, gastropods) are the main groups of soil macrofauna. These organisms are responsible for changing the habitat structure, in terms of its physical, chemical and structural properties, contributing to different soil functions such as decomposition and nutrient cycling, water infiltration (e.g. by burrowing behaviors), suppression of pests and diseases, and as predators regulating other biota (Wurst et al., 2012). They have a direct positive effect on plant growth and yield, but they can also represent the cause of some deleterious effects on crops.

Soil organisms can be classified also according to their functionality, which helps to elucidate about their ecological roles within soil ecosystems. Turbé et al. (2010) suggested the use of three all-encompassing functional groups: chemical engineers, biological regulators, and ecosystem engineers. Chemical engineers consist of organisms directly involved on $\mathrm{C}$ and nutrient cycling such as decomposers and transformers. Biological regulators are responsible for controlling the dynamics of biological populations (i.e. pests, diseases), thus promoting the resilience and stability of soil ecosystems. Ecosystem engineers are responsible for soil structure maintenance by promoting aggregate stability, the formation of pore networks, and the development of complex bio-structures.

\section{- Soil food webs}

Soil biodiversity is connected throughout an intricate network of feeding relationships across multiple trophic levels, whose links can be depicted in food webs (Scheu and Falca, 2000; Brose and Scheu, 2014). The different levels of complexity that exist in soil biota are controlled holistically in a bottom-up and top-down regulation system, in relation to the inter- and intra-specific interactions. Food webs provide a framework for describing and quantifying the main interactions between species, as well as studying 
the fluxes of energy and material within the system (Scheu, 2002; Thompson et al., 2012). Food webs offer an integrative insight into how species are organized within communities, how they relate to the abiotic environment and, ultimately, inform about the mechanisms through which biodiversity influences ecosystem functioning (Thompson et al., 2012). Understanding the structure and dynamics of soil food webs is however a challenging task. Soils' physical inaccessibility and opaqueness make direct observations of species' interactions unfeasible. Recently, molecular gut analysis and stable isotope approaches have proved invaluable for unveiling the trophic relationships required to construct soil food webs (Brose and Scheu, 2014).

Soil food webs are composed by two main systems, one herbivory-based ("green" food webs) and other detritus-based ("brown" food webs). In belowground herbivory food webs plant roots constitute the main basal resource, grazed by phytophagous nematodes and insects, which in turn are preyed upon by a predaceous community with several levels (de Ruiter et al., 1998). Most primary production is nonetheless not consumed and enters the detritus pool underlying brown food webs (Moore et al., 2004). The detritus pool that supports brown food webs consists on more or less recalcitrant nonliving organic materials. Two energy channels have been identified within brown food webs: i) the bacterial energy channel, with bacteria as primary decomposers, and ii) the fungal energy channel, in case fungi play that role (Hedlund et al., 2004). This bacterialfungal energy channel concept generally assumes a reasonably well separated community of detritivores/microbivores (Geisen, 2016). However, increasing evidences suggest that omnivore and feeding plasticity is generalized within soil food webs (Digel et al., 2014), not only at higher trophic levels but also within detritivores/microbivores guilds (Geisen, 2016). This whole network, including the different energy channels, is stabilized by an extensive number of trophic and non-trophic interactions at multiple spatial and temporal scales (Hedlund et al., 2004; Wardle, 2006). The importance of bottom-up and top-down regulation varies within soil food webs, among trophic levels, and energy channels (Wardle, 2006) Interactions between systems occur not only at predator levels (de Ruiter et al., 1998), but also at the bottom-level between autotrophs and decomposers, either linked by asymmetric metabolic capabilities (Naeem et al., 2000) or resource competition (Kaye and Hart, 1997). Non-trophic interactions, such as the activity of soil engineers, are also thought to promote diversity and reduce competitive interactions, thus contributing to stabilize soil food webs (Wardle, 2006) 
The vulnerability of each trophic level to environmental changes has been associated to their inherent ability to disperse in time and space. Hence, the bacterial pathway is thought to be less vulnerable than the fungal pathway (Hedlund et al., 2004). Organisms associated to root-based food webs are more spatially constrained and therefore show higher vulnerability to changes affecting plant community (Hedlund et al., 2004). Besides, organisms at higher trophic levels tend to be more vulnerable to disturbance than those belonging to lower trophic levels, which might reduce the length and connectance in soil food webs at early stages of succession after disturbance (Moore, 1994).

\section{- Relationships between soil ecosystem structure and functions}

Structural changes in natural soil communities do not necessarily lead to functional losses. However, in some situations, these changes might be regarded as early warnings of potential impairments in soil ecosystem functioning. This interplay between community structure and functioning has been subject of intense debate among soil ecologists (Wardle et al., 2000). Soil communities have a high level of redundancy between species (Hunt and Wall, 2002). For this reason, it is normally assumed that small to moderate changes in soil ecosystem structure can be accommodated by the presence of a high number of species with similar roles within the community (van Straalen, 2004). Soil functioning is thought to be unaffected by structural changes until the tipping point is reached, where the ecological role of some species or groups of species cannot be compensated by any others still present in the community (Hedlund et al., 2004). Therefore, soil biodiversity works as an insurance against potential disturbing events (van Straalen, 2002).

A vast number of experimental studies performed in soil ecosystems have proved the "redundant species" hypothesis, leading to the general belief that functional endpoints are less sensitive than structural endpoints for the assessment of environmental integrity (van Straalen, 2002). Focusing only on soil functions may allow the protection of vital soil processes but gives little indication of the effects on soil communities (Schaeffer et al., 2010). Although convenient from an anthropocentric point of view, soil biodiversity should have an intrinsic value that would be worth conserving (Römbke et al., 2005). Understanding how structure affects functioning is essential for long-term soil 
monitoring and management (van Straalen, 2002). An alternative hypothesis ("rivet" hypothesis) states that any species loss, to any extent, always leads to an ecosystem function decrease because every species holds a specific contribution to the functioning and this contribution is eliminated from the system in case of species removal (van Straalen, 2002). This hypothesis assumes that ecosystem functioning decreases linearly with increasing species loss. Such linear responses have been less frequently documented in soil ecosystems. Ramsey et al. (2005) did not find evidences of functional redundancy when comparing the results of functional endpoints (e.g. soil respiration, soil microbial biomass, above- and below-ground plant biomass) with changes in microbial community structure, studied with phospholipid fatty acids analysis (PLFA), along a long-term metal contamination gradient. Both structural and functional endpoints were non-responsive at low contamination levels, but increased linearly towards higher contamination levels (Ramsey et al., 2005). Furthermore, contrary to what is normally assumed, functional endpoints were more sensitive than structural ones because the linear increase started at low contamination levels (Ramsey et al., 2005). An additional theory, the "idiosyncratic" hypothesis, states that no relationship exists between changes in soil community structure and soil functioning (van Straalen, 2002). Idiosyncratic hypothesis suggests that not all species have equal contribution to ecosystem processes (i.e. key functional groups may have disproportionate importance) and, therefore, species richness does not provide insight into soil functioning (Nielsen et al., 2011).

\section{- Effects of contaminants on soil ecosystem structure}

When a contaminant enters the soil, not all the species are expected to be similarly affected. As previously mentioned, soil ecosystems harbor a vast diversity of organisms with different life histories, morphologies, physiologies and behaviors, leading to different responses to specific contaminants (van Straalen, 2004). Toxicological processes such as uptake, sequestration, biotransformation and excretion of specific contaminants vary considerably between and even within species, and greatly determine organism vulnerability (van Straalen, 2004). Furthermore, species' vulnerability depends also on the route of entrance of the contaminant into the soil ecosystem. Different species may become more or less prone to be affected by any contaminant 
depending on the relevance of the exposure route according to their own life traits. Hard-bodied organisms and those living in the top soil layer are likely more exposed to contaminants via food, while those soft-bodied and soil-dwelling organisms living in the pore space are more exposed to substances maintaining a soluble fraction in the pore water (O'Halloran, 2006). Organisms whose main food items or prey (i.e. predators) may become highly contaminated are expected to intake greater amounts of specific contaminants (van Straalen et al., 2001).

Alterations resulting from any of these situations may lead to selective declines in species abundance and ultimately to an impaired community in terms of richness, diversity, evenness, and many other metrics available to evaluate natural communities. A large body of surveying studies performed along metal gradients in soil ecosystems has provided significant evidences of pollutant-induced changes in virtually all kinds of soil communities and related biota: plants (e.g. Salemaa et al., 2001; Koptsik et al., 2003; Dazy et al., 2009; Naveed et al., 2014), soil microbes (e.g. Ramsey et al., 2005; Wang et al., 2007; Naveed et al, 2014), soil invertebrates (e.g. Zaitsev and van Straalen, 2001; Nahami and Lavelle, 2002; Nahmani et al, 2005; Jung et al., 2008; Chen et al., 2009; Santorufo et al., 2012; Naveed et al, 2014), and wild bees (e.g. Moron et al., 2012). The type of structural change seems less generalized, certainly depending on the extent of the gradient, the kind of community, and many other external factors specific to each situation. Ecological indices are, in some situations, unable to capture the effects of contaminants. If the dominant pollution-sensitive species do not disappear completely, an erroneous increase in index may occur (Cortet et al., 1999). On the other hand, indirect effects or compensatory mechanisms may favor some groups leading to higher total abundances in contaminated sites (Pedersen et al., 1999; Nahami and Lavelle, 2002). Either situation represents an alteration in community structure whose effects on stability are difficult to predict in the long-term. Ecological indices must therefore be used carefully, preferably only in highly contaminated sites (Cortet et al., 1999). Trait-based approaches have been increasingly adopted to assess the effects of contamination on soil biota. The concept of functional traits provides information about the mechanisms through which soil contaminants affect communities, thus becoming more easily relatable to ecosystem functioning (Hedde et al., 2012; Moretti et al., 2016).

\section{Soil ecosystem functions}


Soil health is defined as "the capacity of soil to function as a vital living system to sustain biological productivity, maintain environment quality and promote plant, animal and human health" (Doran et al., 1996; Doran and Zeiss, 2000). Soil health is directly related to soil quality. Although both terms have been often used interchangeably, soil quality refers to the capacity of the system for performing specific functions whereas soil health refers to its overall condition (Lal, 2016). Soil health depends mainly on the maintenance of four major functions, which in turn are determined by a combination of different biological processes (Kibblewhite et al., 2008): i) carbon transformations, ii) nutrient cycling, iii) soil structure maintenance, and iv) biological population regulation. The biological processes contributing to these functions are provided by a set of key functional groups of soil living organisms (see previous section of soil biodiversity).

Soil quality/health is determined by a combination of multiple physical, chemical, and biological properties. Some of these properties can be used as monitoring tools/indicators to assess changes in specific soil functions and therefore on the overall quality/health of the soil ecosystem as a consequence of different management practices, natural disturbances (e.g. climate changes) or contamination (e.g. Doran and Zeiss, 2000; Schloter et al., 2003; Gil-Sotres et al., 2005; Marinari et al., 2006; Stankovic et al., 2014; Calzolari et al., 2016; Constantini et al., 2016; Stone et al., 2016). Table 1 lists some of the most widely used indicators.

\section{- Carbon transformations}

Soil organic matter (SOM) in an essential constituent of terrestrial ecosystems (1-10\% of total soil biomass; Horwarth, 2007), which comprises soil biota and vegetal and animal materials that return to the soil and go through the decomposition process, becoming a by-product of decomposition (Craswell and Lefroy, 2001; Bot and Benites, 2005; Horwarth, 2007). Among others, SOM provides nutrients and habitat to soil biota and contributes to particle aggregation, enhancing the physical structure of soils and then promoting aeration, water infiltration, and resistance to erosion and crusting (Bot and Benites, 2005; Horwarth, 2007). It is also involved in the regulation of atmospheric gases (e.g. $\mathrm{CO}_{2}, \mathrm{~N}_{2} \mathrm{O}, \mathrm{CH}_{4}$ ) and in the adsorption/retention of chemicals such as metals and pesticides by organo-mineral complexes (Bot and Benites, 2005; Horwarth, 2007). 
Plant remains (e.g. leaf and woody litter, old plant roots, crop residues) constitute the main source of SOM. They normally contain $60-90 \%$ of moisture while the remaining dry matter includes basically $\mathrm{H}, \mathrm{C}$ and $\mathrm{O}$, followed by small amounts of $\mathrm{N}, \mathrm{S}, \mathrm{P}, \mathrm{K}, \mathrm{Ca}$ and $\mathrm{Mg}$, and a number of elements in smaller quantities such as $\mathrm{Cu}, \mathrm{Mn}, \mathrm{Zn}$ and $\mathrm{Fe}$ (Bot and Benites, 2005). These elements are integrated in more or less organic complex structures (e.g. sugars, cellulose, hemicellulose, starch, lignins, proteins, waxes, resins; Horwarth, 2007). Therefore SOM is the main source of C and energy for soil biota.

The transformations undergone by the soil organic C (SOC) are part of the degradation, mineralization and humification cycle of the SOM by the action of living organisms (Figure 2). Fresh organic residues undergo first through a decomposition process that involves physical fragmentation, chemical degradation, and leaching of organic substances (Coleman et al., 2004; Barrios, 2007). The physical breakdown is performed mainly by medium-size invertebrates during their feeding activity, facilitating the colonization and invasion of soil microorganisms (Barrios, 2007). This process is followed by the chemical degradation of detritus in which microorganisms change the $\mathrm{C}$ structures of complex organic molecules, releasing simpler compounds generally soluble (e.g. carbohydrates, proteins, amino acids, etc.). Some of these compounds suffer a primary mineralization process where they are transformed into soluble (e.g. $\mathrm{NO}_{3}{ }^{-}$) and/or gaseous (e.g. $\mathrm{CO}_{2}$ ) inorganic compounds. The rest is used for the formation of new increasingly complex molecules of colloidal nature and dark color called humus. The humification process occurs through several oxidation and hydrolysis reactions leading to substances with increasing $\mathrm{C}$ and $\mathrm{H}$ content and lower $\mathrm{O}$ content compared to the original fresh residues (Horwarth, 2007). Therefore, humic substances (humic acids, fulvic acids, hymatomelanic acids and humins; Tan, 1994) are relatively more stable and resistant to decomposition.

The processes involved in SOM turnover are affected by several factors such as climate conditions (e.g. temperature, precipitation), soil properties (e.g. $\mathrm{pH}$, salinity, texture, moisture content, clay mineralogy), living organisms present in the system, quantity of annual fresh organic inputs and organic matter quality (e.g. litter with low C:N ratios degrades faster than litter with high C:N ratios) (Bot and Benites, 2005; Stockman et al., 2013; Smith et al., 2015). In addition, anthropogenic soil contamination might influence SOM turnover. 
Numerous studies have evaluated the effects of anthropogenic contaminants on SOM turnover in terrestrial ecosystems, with special attention to metals and pesticides (mainly herbicides, fungicides, and insecticides). Soil contaminants might affect plant productivity and therefore alter the quantity and/or quality of fresh organic inputs reaching the soil (e.g. Cheng, 2003; Marshall et al., 2003; Nagajyoti et al., 2010; Sánchez-Bayo, 2011). They might also damage soil biota (microbial and faunal communities), leading to direct toxic effects and changes in species composition and community structure (e.g. Kozdrój and van Elsas, 2001; van Straalen, 2004; Giller et al., 2009; Pelosi et al., 2014; Riah et al., 2014; Stankovic et al., 2014; Pisa et al., 2015; Zaller et al., 2016), which in turn might affect SOM turnover. Decreasing SOM decomposition might lead to the accumulation of non-transformed organic matter in soils affected by anthropic activities and therefore to the immobilization of essential nutrients due to the hindered mineralization (e.g. Cotrufo et al., 1995; Lomander and Johanson, 2001; Förster et al., 2006; Zaller et al., 2016), affecting other soil functions. The intensity of these effects depends on the contamination degree but also on the properties of the soil, and the prevailing climate conditions.

In general, scientists agree on the negative effects of metal contamination on SOM turnover both in temperate (e.g. Creamer et al., 2008; Freitas et al., 2014) and tropical (e.g. Niemeyer et al., 2012a, 2012b) regions. Most of the studies show reducing litter decomposition with metal pollution and relate this to alterations in soil fauna feeding activity and microbiological parameters (e.g. soil basal respiration, microbial biomass $\mathrm{C}$, enzyme activities such as dehydrogenase, $\beta$-glucosidase and cellulose), but also to the sub-optimal conditions prevailing in metal-contaminated soils. Results from a metaanalysis on the long-term effects of metal contamination $(\mathrm{Cd}, \mathrm{Cu}, \mathrm{Pb}$ and $\mathrm{Zn})$ on soil $\mathrm{C}$ and $\mathrm{N}$ cycling showed decreasing organic $\mathrm{C}(\mathrm{OC})$ and total $\mathrm{N}(\mathrm{TN})$ contents in metalcontaminated soils, due to the lower plant biomass production and consequently to the reduced input of fresh organic remains into the soil, and/or increasing $\mathrm{C}: \mathrm{N}$ ratios indicative of hindered mineralization (Zhou et al., 2016). Greater decreases of OC and TN were found in soils with acidic $\mathrm{pH}(<6.5)$ and sandy texture and in climate zones with mean annual temperatures around $10-20{ }^{\circ} \mathrm{C}$ and mean annual precipitations $>1000$ mm (Zhou et al., 2016).

The effects of pesticides on SOM turnover are in general diverse. This might be attributable to the wide range of physical and chemical characteristics of the pesticides 
applied, but also to the edaphic and climate environment that largely determines their degradation (e.g. Laabs et al., 2000; Chowdhury et al., 2008; Riah et al., 2014; Delcour et al., 2015). Some microorganisms might use pesticides as source of energy and nutrients (e.g. Johnsen et al., 2001; Riah et al., 20014), enhancing the processes in which they are involved (e.g. enzyme activation), whereas pesticides might be toxic for other soil living organisms (e.g. Sánchez-Bayo, 2011; Riah et al., 20014; Pisa et al., 2015; Zaller et al., 2016) negatively affecting SOM turnover. Riah et al. (2014) identified general response profiles of $\mathrm{C}$ cycling enzymes after pesticide exposure, showing an inhibition effect of dehydrogenase activity, activation of cellulose especially by insecticides, and no clear response of $\beta$-glucosidase. If pesticide application kills and/or reduces the activity of some specific groups, other organisms may benefit from this (new substrate and/or lack of competition), leading among others to an activation of the processes involved in SOM turnover (e.g. Chowdhury et al., 2008). Among pesticides, herbicides have a direct effect on the quantity and/or quality of fresh organic residues entering the soil (e.g. Wardle et al., 1994; Marshall et al., 2003). When strong reductions on plant litter occur, herbicides indirectly affect soil microbial and faunal communities by decreasing food and habitat availability (e.g. Marshall et al., 2003; Sánchez-Bayo, 2011), which in turn might affect SOM turnover. On the contrary, fungicides and insecticides might have a more direct toxic effect on faunal communities (e.g. Bünemman et al., 2006; Sánchez-Bayo, 2011; Pelosi et al., 2014), affecting the processes in which they are involved such as SOM breakdown (e.g. Burrows and Edwards, 2004; Förster et al., 2004, 2006; Da Silva et al., 2010; Zaller et al., 2016).

Often less studied regarding SOM related functions, pharmaceuticals might appear in soils due to sludge/biosolid applications. Bioactive pharmaceuticals might affect soil microbial communities. Gielen et al. (2011) found that sludge application induced changes on soil microbial functioning observed by the increase on $\mathrm{CO}_{2}$ respiration, decrease on the microbial biomass carbon and changes in substrate utilization affinities. These changes in the microbial fingerprint helped also the soil to cope with long-term pharmaceuticals exposure, where resistant microbes prevailed and mitigated responses, by helping degrading those compounds. The field study of Adler et al. (2016) showed that soil invertebrates were affected by the exposure to the veterinary pharmaceutical ivermectin through dung application, inducing changes on their diversity but also on their function in soil. 


\section{- Nutrient cycling}

Nutrients are essential elements for the growth and development of living organisms; macronutrients are needed in relatively large quantities $(\mathrm{N}, \mathrm{P}, \mathrm{K}, \mathrm{Ca}, \mathrm{Mg}$ and $\mathrm{S})$ while micronutrients in lower concentrations (e.g. Fe, $\mathrm{Zn}, \mathrm{Mn}, \mathrm{Cu}, \mathrm{B}, \mathrm{Mo}, \mathrm{Ni}, \mathrm{Co}, \mathrm{Cr}, \mathrm{Se}, \mathrm{Sn}$ ). These elements occur in gaseous forms (e.g. $\mathrm{N}_{2}$ ), as part of mineral compounds (e.g. apatite), inorganic ionic forms (e.g. $\mathrm{NH}_{4}{ }^{+}, \mathrm{NO}_{3}{ }^{-}, \mathrm{PO}_{4}{ }^{3-}, \mathrm{SO}_{4}{ }^{2-}$ ) and/or organic forms (Cbased compounds) (MA, 2005). Plants generally take up nutrients in ionic forms, soil fauna in organic forms (consumption of living and/or dead tissues) and microorganisms in any mineral and/or organic form (MA, 2005). Nutrient cycling refers to the movement of nutrients within and among the different soil biotic and abiotic components. Transformations from organic to inorganic forms are mediated by living organisms and largely determine soil fertility, which supports among others plant growth (Bot and Benites, 2005, MA, 2005; Paul, 2007; Smith et al., 2015). The major functional groups of soil living organisms involved in nutrient cycling are the microfood web and litter transformers, as for the $\mathrm{C}$ transformations, and the root/rhizosphere biota (e.g. N-fixing bacteria, mycorrhiza fungi, root herbivores) (Wall et al., 2012).

As previously described, SOM is the main source of nutrient to soil living organisms; decomposition and mineralization processes release nutrients from organic materials (Figure 2) (Bot and Benites, 2005; Horwarth, 2007). Therefore, any effect of contaminants in SOM turnover affects also nutrient cycling (e.g. if litter input and/or decomposition are impaired nutrient mineralization will be also affected causing an imbalance in the nutrients availability for living organisms and consequently a loss in soil quality/health). Most of the studies regarding soil contamination and nutrient cycling have been focused on $\mathrm{N}$. Contaminants might affect different microbialmediated $\mathrm{N}$ transformations $\left(\mathrm{N}_{2}\right.$-fixation, ammonification, nitrification, and denitrification), thus altering the overall soil $\mathrm{N}$ mineralization rate. In general metal contamination negatively affects $\mathrm{N}$ cycling, although this depends on multiple factors such as the contamination degree (some metals are essential nutrients to living organisms so low concentrations might have beneficial effects), the oxidation state of the metals, the characteristics of the soil (e.g. pH, texture, organic matter content), and the climate conditions. Numerous studies have found detrimental effects of high soil 
metal concentrations on urease activity (key enzyme in $\mathrm{N}$ cycle by catalyzing the hydrolysis of urea into $\mathrm{CO}_{2}$ and $\mathrm{NH}_{3}$; e.g. Li et al., 2009; Yan et al., 2013), $\mathrm{N}_{2}$-fixation (e.g. Filip, 2002; Chaudhary et al., 2004), ammonification (e.g. Kostov and van Cleemput, 2001), nitrification (e.g. Megharaj et al., 2003; Li et al., 2015), denitrification (e.g. Sobolev and Begonia, 2008; Liu et al., 2016), and overall N mineralization (e.g. Nwuche and Ugoji, 2008; Zhang et al., 2010). However, some studies have reported also beneficial effects and even long-term recovery of $\mathrm{N}$ cycling due to the development of a metal-tolerant microbial community (e.g. Megharaj et al., 2003; Yang et al., 2007).

Studies concerning the effects of pesticides on N cycling offer variable and contrasting results depending on the $\mathrm{N}$-transformation evaluated, specificity of the applied compound, application dose, and repeatability of the application. A global analysis on the effects of pesticides on soil enzymes shows that urease activity might be either unaffected or inhibited, except in the case of some fungicides (e.g. carbendazim and validamycin) which tend to stimulate its activity (Riah et al., 2014). Detrimental effects of pesticide application on $\mathrm{N}_{2}$-fixation has been observed due to the disruption of the chemical signaling between the $\mathrm{N}_{2}$ fixing bacteria and the host plant (Fox et al., 2007), decreasing the symbiotic efficiency, or changes in the bacterial community composition (Angelini et al., 2013). In many cases, pesticide application at low and/or field concentration rates do not have significant effects on ammonification, nitrification and denitrification processes, while higher doses and/or repeated applications might damage these microbial-mediated $\mathrm{N}$ transformations (e.g. Muñoz-Leoz et al., 2013; Crouzet et al., 2016; Zhang et al., 2016).

Less attention has been paid to the effects of metals and pesticides on other essential nutrients such as $\mathrm{P}$ and $\mathrm{S}$. For both nutrients, evaluations have been made through changes in enzyme activities such as acid/alkaline phosphatase (key enzymes in P cycle by catalyzing the hydrolysis of esters and anhydrides of phosphoric acid) and arylsulfatase (key enzyme in S cycle by catalyzing the hydrolysis of sulfate esters). Soil metal contamination negatively affect phosphatase (e.g. Wang et al., 2007; Li et al., 2009; Zhang et al., 2010; Renella et al., 2013) and arylsulfatase (e.g. Haanstra and Doleman, 1991; Kandeler et al., 2000) activities. Pesticides (mainly herbicides, fungicides, and insecticides) seem to have an inhibitory effect on phosphatases whereas no influence on arylsulfatase activity (Riah et al., 2014). 
Pharmaceuticals might also induce changes in nutrient cycling as shown in the study of Cycoń et al. 2016, where the effects of non-steroidal anti-inflammatory drugs (e.g. diclofenac, ibuprofen) in soils were evaluated looking at several soil enzymatic activities, substrate-induced respiration, nitrification and ammonification processes, or even on the diversity of culturable bacteria and fungi. In this case, responses were present as a stimulatory effect on soil respiration and soil enzymes, with an increase on the number of heterotrophic bacteria and fungi capable of using these chemicals as source of $\mathrm{C}$ and energy. These patterns show that these drugs can unbalance and disturb soil functions regarding nutrient cycling.

\section{- Soil structure maintenance}

Soil living organisms are much more than mere inhabitants of soil ecosystems. Through their activity, organisms tend to aggregate the solid constituents and create pore networks, thus generating structure and allowing the maintenance of the soil habitat and the regulation of the soil-water cycles (Kibblewhite et al., 2008). They are inextricably and functionally intertwined with soil mineral and organic materials, creating a feedback loop through which they affect the structural stability of the system over a range of different spatiotemporal scales, but at the same time they are affected reciprocally through habitat provision (Brussard et al., 1997; Young et al., 1998; Havlicek and Mitchell, 2014). Lavelle et al. (2006) identified five relevant scales related to soil functioning, with processes successively embedded and emergent properties arising at higher scales as result of small-scale processes: i) microbial biofilms (smallest habitat in soil systems constituent by micro aggregates); ii) micro-food webs (habitat outside micro aggregates); iii) functional domains of ecosystem engineers (habitat at the scale of centimeters to decimeters where ecosystem engineers and abiotic factors determine soil architecture through the formation of aggregates and pores of different sizes; iv) mosaics of functional domains at plot scale (patchy distribution of ecosystem engineers' functional domains); and v) landscape scale (coexistence of different ecosystems). Plants are thought to have the highest influence on soil processes determining soil structure followed by invertebrate ecosystem engineers, litter transformers and the remaining soil food web components acting more localized (Lavelle, 1996). Plants modulate soil structure and aggregate stability directly through 
root penetration, water extraction and root exudation, among others, or indirectly by promoting root-associated communities of faunal ecosystem engineers (Wolters et al., 2000; Bronick and Lal, 2005; Schweitzer et al, 2012). Ecosystem engineers (e.g. soil macroinvertebrates) change soils' physical structure, creating macro pores and channels through their feeding and burrowing activities (Bardgett, 2005; Nahmani et al., 2005). Earthworms are, by far, the most well studied group in soil ecotoxicology approaches due to their key functional roles in soil and high sensitivity to contamination, which allows their use as bioindicators (Römbke et al., 2005). Earthworm's contribution to soil structure depends on the specific ecological characteristics of each species. The ability to sustain diverse earthworm communities, encompassing different ecological strategies, contributes significantly to soil structure maintenance (Blouin et al., 2013). In this sense, earthworms, along with other macrofauna groups, can be used as management tools within strategies for restoration and remediation of contaminated soils (Snyder and Hendrix, 2008; Blouin et al., 2013).

As any other process mediated by living organisms, soil structure formation and maintenance might be greatly affected by soil contamination. Several studies suggest that pollutants lead to important decreases in the communities of soil invertebrate ecosystem engineers, considering also their activity such as burrowing behavior, inducing strong effects in soil structure. This has been well documented for metals (e.g. Leveque et al., 2014; Naveed et al., 2014) and pesticides (e.g. Capowiez et al., 2003, 2006; Capowiez and Bérard, 2006). Naveed et al. (2014) provided an outstanding overview of the relationships between soil biodiversity and soil structure along a gradient of $\mathrm{Cu}$ contamination. Correlations were found between various indicators of soil biological community structure (e.g. plants, earthworms, nematodes, bacteria, and fungi) and contamination-induced changes in soil physicochemical properties (e.g. total porosity, air permeability, water retention, etc.) (Naveed et al., 2014). Besides, the authors found drastic reductions in earthworm density, particularly in endogeic and anecic species, that were concomitant with reductions in soil porosity and average pore diameter. Leveque et al. (2014) also showed reduced vertical burrowing behavior in metal-exposed earthworms which resulted in lower incorporation of straw provided at the surface. On the contrary, other studies have found a predominance of macroinvertebrates activity at the soil surface in in situ metal-contaminated soils (Nahmani et al., 2005). 
On the other hand, only few studies have assessed the effects of contamination on the relationship plant community-soil structure and yielded so evident causal relationships. Understanding how contaminants affect plant diversity, although critical as first-step, may not necessarily inform about local impoverishments in soil structure. Evidences suggest that specific traits of plant species or groups can become stronger determinants than diversity (Bardgett, 2005).

\section{- Biological population regulation}

An inherent property of healthy ecosystems is the capacity to self-regulate. Healthy ecosystems must maintain its structure and function over time and must be able to cope with external pressures (Constanza and Mazeau, 1999). Maintaining biodiversity is critical to ensure ecosystem stability because it dilutes the strength of species interactions within food webs (McCann, 2000; Worm and Duffy, 2003; Cardinale et al., 2012). Evidences suggest that complex communities with few strong links embedded in a majority of weak interactions have greater stability than communities where few strong links dominate (Neutel et al., 2002). Such communities not only show greater functional stability but they are also less prone to abrupt structural changes (Neutel et al., 2002). This is particularly important after disturbance events, when the capacity for renewal and reorganization of ecosystems is required to avoid shifts leading to novel undesirable states (Elmqvist et al., 2003). Soil complexity leads to equally complex soil communities (Buchkowski, 2016). These communities are normally self-organizing entities determined by the same spatially and temporally dynamic factors that hierarchically affect soil ecosystems at multiple levels (Lavelle, 2012). Despite the dynamism conferred by resource heterogeneity and local disturbance frequency, healthy soils encompass complex ecological networks that allow them to regulate and maintain diverse soil populations (Ettema and Wardle, 2002). These multitrophic interactions play a central role in the response of ecosystems to environmental and anthropogenic changes and occur at all levels of ecological organization (van der Putten et al., 2004).

Human-induced disturbances often lead to long-term detrimental impacts on soil food webs complexity. This may have serious impacts on the ability of ecosystems to regulate the biological populations. The ecological interactions underlying the regulation of soil populations are poorly understood, when comparing to other 
ecosystems. Although top-down regulation has been suggested to have limited importance in soil food webs, recent evidences suggest that trophic cascades might actually occur in herbivore/pathogen soil pathways actively controlling these groups and leading to improved primary production (Kulmatiski et al., 2014).

Most research on the effects of soil contamination in biological regulation has dealt with pest control in agriculture ecosystems, control of soil-borne diseases, and the interacting effects between contamination and invasive species. The destruction of pests' natural enemies is increasingly regarded as a significant side-effect of pesticide application because it might lead to increasing virulent secondary outbreaks (Paoletti and Pimentel, 2000). Several studies reported decreasing performance of natural predators exposed to pesticides (e.g. Baatrup and Bayley, 1993; Michalková and Pekár, 2009). Besides, field studies generally show higher abundance and diversity of natural predators in pesticidefree agroecosystems (e.g. Hole et al., 2005). Such decrease in the biocontroller community (predators, microbivores, and hyperparasites; Kibblewhite et al., 2008) suggests an impaired regulation of pest populations that might need to be compensated with external control measurements.

One well-known beneficial arthropod that can regulate pest insects is the ladybird beetle (Coccinella septempunctata). This arthropod can deposit semiochemicals on leaf surface, inducing an avoidance behavior in parasitoid aphids (Nakashima et al., 2004). When $C$. septempunctata is affected by the presence of contaminants, its function as biological regulator is impaired. The neonicotinoid imidacloprid was used in laboratory microcosms to evaluate deleterious effects on its life-cycle (Yu et al., 2014). On their study, Yu et al. (2014) concluded that application rates of imidacloprid higher than 3.42 $\mathrm{g}$ a.i. $\mathrm{ha}^{-1}$ were expected to already induce deleterious effects on C. septempunctata, which is considerably lower that the application rate from China that ranges 15-60 g a.i. $\mathrm{ha}^{-1}$. With this overview, the biological regulation of pests will be impaired by this pesticide and therefore higher chemical application rates will need to be carried out to control aphids as well as other pests.

It is not clear whether pesticides can also affect regulation within decomposer food webs. Salminen et al. (1997) showed that terbuthylazine reduced the top-down regulation of predatory mites over an artificial decomposer community. Natural soil ecosystems are nonetheless more complex and few evidences for trophic cascades in decomposer- and symbiont-based have been noticed (Kulmatiski et al., 2014). 
Soil contamination may also favor less sensitive, opportunistic or even invasive species whose life traits enable withstanding such adverse conditions and end up benefiting from the lower competition resulting from the displacement of native sensitive species. Yang et al. (2007) compared the invasive plant species Solidago canadensis to noninvasive grassland species for their tolerance to metal contaminated soils. The results suggest that $S$. canadensis can withstand higher $\mathrm{Pb}$ concentrations, by reducing its uptake, conferring this species a competitive advantage in $\mathrm{Pb}$-contaminated soils.

\section{Soil ecosystem services}

The preceding sections have pointed how soil contamination influences soil biodiversity and, by doing so, how it interferes with vital processes governing soil ecosystems (i.e. soil ecosystem functions). Although the obvious next step consists on relating such effects on soil ecosystem functions to the delivery of soil-based ecosystem services or goods, this requires sound ecological valuation and the best approach to achieve it is still unclear (Calow, 2015; Kapustka and McCormick, 2015).

The increasing number of contaminated soils at global scale due to anthropogenic activities results in large and severe impacts on soil ecosystems services. In 2005, the MA reported that $60 \%$ of ecosystem services were degraded and/or used unsustainably and related this issue to pollution, habitat change and overexploitation of natural resources among other factors (MA, 2005). Since the economic valuation of soil ecosystem services is a difficult task and often lacking at the policymaking level, the costs of services losses can go unnoticed (TEEB, 2009). However, in the last years, the concept of ecosystem services has been considered a promising approach for environmental management and decision making (Maltby et al., 2017). In fact, the evaluation of soil ecosystem services in environmental risk assessments of contaminants has long been advocated (Cairns and Nielderlehner, 1994). Assessing ecosystem services is compatible and complementary to traditional endpoints used in environmental risk assessment for soil ecosystems (Maltby et al., 2017). Faber and van Wensem (2012) provided an extensive group of structural and functional endpoints and indicators that are clearly linked to specific ecosystem services (some indicators/endpoints related to soil ecosystem functions and services are provided in Figure 1). If properly addressed within the context of sound ecosystem services 
frameworks, these endpoints can provide an encompassing perspective of human wellbeing and environmental health (Faber and van Wensem, 2012). Furthermore, such approach provides a common currency that facilitates the communication among relevant stakeholders (Maltby et al., 2017).

In spite of its great importance, only few studies clearly focus on the ecosystem service approach in real scenarios, looking individually at those services but also using a holistic framework to integrate them.

\section{- Provisioning services}

Soil contamination might affect provisioning services such as water and food supply and genetic diversity. Soil contaminants can reach groundwater and/or surface waters, affecting the quality of water resources (e.g. drinking water) (Moss, 2008; Lerner and Harris, 2009; EC, 2013). Over 126,000 sites with contaminated groundwater were recently identified in the US alone and the remediation cost estimation exceeded 127 billion US dollars (NRC, 2013). Soil contamination can reduce crop yield, decreasing food availability, and impair food safety (EFSA, 2012a, 2012b, 2012c; Udeigwe et al., 2015). Plants can uptake contaminants through their roots and leaves and these substances can biomagnificate within food chains, leading to disease and/or death of animals including human beings (Vargas Rojas et al., 2016). The case study presented by Ding et al. (2016) in China highlights the main accumulation of $\mathrm{Cd}$, As and $\mathrm{Pb}$ in rice grain (Oryza sativa) that will not only decrease rice production but also present health risks to consumers. In addition, and by changing the ability to sustain a certain diversity of plant species, the presence of metals in soils can change the water holding capacity, affecting therefore other soil living organisms like invertebrates, essential for different functions and services provided by soil ecosystems. In other cases soil contaminants (e.g. fertilizers) can stimulate food and fiber production, assuming a benefit for provisioning services (Albizua et al., 2015). The genetic diversity of soil wild species can be impaired due to the inherent toxicity caused by soil contaminants (Jones et al., 2014). Among others, this may affect biotechnology and pharmacy industries since soil microbiota is essential for antibiotic production (Jeffrey et al., 2010; D'Costa et al., 2011). 
Soil contamination might impact regulating services such as air and water quality control, climate regulation, flood regulation and pest and disease control. Soil contaminants (e.g. metals, pesticides, fertilizers, etc.) might be transferred and/or migrate to different ecosystem compartments like the atmosphere and the hydrosphere leading to air and water contamination, respectively. Soil contamination can impact also climate regulation due to changes in $\mathrm{C}$ sequestration and stocks in soils as well as to the emission of greenhouse gases (e.g. $\mathrm{CO}_{2}, \mathrm{~N}_{2} \mathrm{O}$ ) (Zhou et al., 2014; Duran et al., 2016). Soil contaminants can negatively impact flood regulation, if the vegetation growing on the affected area is hampered. However, in other cases, soil contaminations might have a positive feedback on the regulation of flood events (e.g. vegetation growth can be stimulated by $\mathrm{N}$ deposition). In relation to pest control, the effects of soil contaminants might be contradictory. This is the case of agricultural insecticides. While they are design to control specific pests, insecticides also affect non-target organisms. This brings a specific concern on soil food webs and on the interspecific relations that control pest dissemination. The review carried out by Chagnon et al. (2015) pointed that predator species can be considered at risk when neonicotinoids are used, reflecting on the impairment of the ecosystem service they represent. The latter can easily be converted into a monetary scale. Losey and Vaughan (2006) estimated a cost of 13.6 billion US dollars in relation to the control of native North American pests along with weather and pathogens. Contamination can also impair the ability of soil systems to regulate soil-borne pathogens and parasites associated to human health problems if soil biodiversity and food web complexity are affected (Wall et al., 2015).

\section{- Supporting Services}

Soil contamination might affect supporting services such as primary production, nutrient cycling and soil formation. Some contaminants can negatively affect primary producers through direct and/or indirect effects (e.g. metals, herbicides) (Wuana and Okieimen, 2011; Krumins et al., 2015), while others can have a positive effect until a certain level (e.g. the use of $\mathrm{N}$ fertilizers can improve primary production in agricultural systems but if $\mathrm{N}$ is applied in excess it can damage crops) (Duran et al., 2016; Tian et al., 2016). Soil contamination can affect nutrient cycling and balance. Some 
contaminants (e.g. metals, pesticides) can affect soil biota biodiversity and functions, indirectly affecting nutrient cycling. The extrapolation of the results obtained in a case study on the application of the neonicotinoid imidacloprid in turfgrass to control the scarab beetle suggests negative effects on soil nutrient cycling due to negative implications on arthropod populations (Peck, 2009). An impaired nutrient cycling and/or soil nutrient imbalance can thereafter induce changes in the soil system formation, if considering for example that $\mathrm{N}$ increase will enhance the accumulation of SOM (De Vries et al., 2009) or the decrease of C stocks in peatlands and tundra soils (Mack et al., 2004; Bragazza et al., 2006).

\section{- Cultural services}

Cultural services provided by soil ecosystems are in general less studied. In most of the cases, they are not clearly defined and integrated within ecosystem service frameworks (Daniel et al., 2012). Soil ecosystems, alone or as part of landscapes, provide endless opportunities for recreation, cultural heritage, folklore, spiritual and religious values, education, etc. (de Groot, 2002; Dominati et al., 2010). Soil contamination might impair cultural services although only few studies have addressed this approach. It is obvious that people enjoy natural areas and aesthetically pleasing landscapes, so any environmental disruption due to anthropogenic activities may change this appreciation (e.g. reducing plant flowering and biodiversity, weedy appearance of the landscape, wildlife animals decline, algae blooms in eutrophic systems, bad odors, etc.). This may lead to decreasing leisure activities (e.g. walking, hiking, camping, swimming, recreational fishing, etc.) thus affecting the cultural and economic values of the contaminated sites.

\section{Acknowledgements}

The authors acknowledge funding to the GLOBALTOX project through the Research Executive Agency (REA-European Commission) under the Marie Skłodowska-Curie actions (H2020-MSCA-IF-2015/H2020-MSCA-IF-2015, Project ID 704332) and to CESAM (UID/AMB/50017/2013) through FCT/MEC (through national funds) and cofunding by FEDER (POCI-01-0145-FEDER-00763), within the PT2020Partnership 
Agreement and Compete 2020. Rui Morgado was granted by the Portuguese Foundation for Science and Technology (FCT-Fundacão para a Ciência e Tecnologia) with a postdoctoral grant (SFRH/BPD/123384/2016).

\section{References}

ADLER, N., BACHMANN, J., BLANCKENHORN, W. U., FLOATE, K. D., JENSEN, J. \& RÖMBKE, J. 2016. Effects of ivermectin application on the diversity and function of dung and soil fauna: regulatory and scientific background information. Environmental Toxicology and Chemistry, 35, 1914-1923.

ALBIZUAA, A., WILLIAMS, A., HEDLUNDD, K. \& PASCUAL, U. 2015. Crop rotations including ley and manure can promote ecosystem services in conventional farming systems. Applied Soil Ecology, 95, 54-61.

ANGELINI, J., SILVINA, G., TAURIAN, T., IBÁÑEZ, F., TONELLI, M. L., VALETTI, L., ANZUAY, M. S., LUDUEÑA, L., MUÑOZ, V. \& FABRA, A. 2013. The effects of pesticides on bacterial nitrogen fixers in peanut-growing area. Archives of Microbiology, 195, 683-692.

BAATRUP, E. \& BAYLEY, M. 1993. Effects of the pyrethroid insecticide cypermethrin on the locomotor activity of the wolf spider Pardosa amentata: quantitative analysis employing computer-automated video tracking. Ecotoxicology and environmental safety, 26, 138-152.

BARDGETT, R.D., 2002. Causes and consequences of biological diversity in soil. Zoology, 105, 367-375.

BARDGETT, R. 2005. The biology of soil: a community and ecosystem approach. Oxford University Press, UK. 242 pp.

BARDGETT, R.D. \& VAN DER PUTTEN, W.H. 2014. Belowground biodiversity and ecosystem functioning. Nature, 515, 505-511.

BARRIOS, E. 2007. Soil biota, ecosystem services and land productivity. Ecological Economics, 64, 269-285.

BLOUIN, M., HODSON, M.E., DELGADO, E.A., BAKER, G., BRUSSAARD, L., BUTT, K.R., DAI, J., DENDOOVEN, L., PÉRÈS, G., TONDOH, J.E. and CLUZEAU, D. 2013. A review of earthworm impact on soil function and ecosystem services. European Journal of Soil Science, 64, 161-182.

BOT, A. \& BENITES, J. 2005. The importance of soil organic matter. Key to drought-resistant soil and sustained food and production. FAO Soils Bulletin No. 80. Food and Agriculture Organization of the United Nations (FAO), Rome, Italy. $95 \mathrm{pp}$.

BRAGAZZA, J., FREEMAN, C., JONES, T., RYDIN, H., LIMPENS, J., FENNER, N., ELLIS, T., GERDOL, R., HAJEK, M., HAJEK, T., IACUMIN, P., KUTNAR, L., TAHVANAINENT, T. \& TOBERMAN, H. 2006. Atmospheric nitrogen deposition promotes carbon loss from peat bogs. Proceedings of the National Academy of Sciences, 103, 19386-19389.

BRONICK, C.J. \& LAL, R. 2005. Soil structure and management: a review. Geoderma, 124, 3-22.

BROSE, U. \& SCHEU, S., 2014. Into darkness: unravelling the structure of soil food webs. Oikos, $123,1153-1156$.

BRUSSAARD, L. 1997. Biodiversity and ecosystem functioning in soil. Ambio, 26, 563-570.

BUCHKOWSKI, R.W. 2016. Top-down consumptive and trait-mediated control do affect soil food webs: It's time for a new model. Soil Biology and Biochemistry, 102, 29-32.

BÜNEMANN, E. K., SCHWENKE, G. D. \& VAN ZWIETEN, L. 2006. Impact of agricultural inputs on soil organisms-a review. Australian Journal of Soil Research, 44, 379-406. 
BURROWS, L. A. \& EDWARDS, C. A. 2004. The use of integrated soil microcosms to assess the impact of carbendazim on soil ecosystems. Ecotoxicology, 13, 143-161.

CAIRNS Jr, J. \& NIEDERLEHNERL, B. R. 1994. Estimating the effects of toxicants on ecosystem Services. Environmental Health Perspectives, 102, 936-939.

CALOW, P. 2015. Why money matters in ecological valuation. Integrated Environmental Assessment and Management, 11, 329-336.

CALZOLARI, C., UNGARO, F., FILIPPI, N., GUERMANDI, M., MALUCELLI, F., MARCHI, N., STAFFILANI, F. \& TAROCCO, P. 2016. A methodological framework to assess the multiple contributions of soils to ecosystem services delivery at regional scale. Geoderma, 261, 190-203.

CAPOWIEZ, Y., BASTARDIE, F. \& COSTAGLIOLA, G. 2006. Sublethal effects of imidacloprid on the burrowing behaviour of two earthworm species: modifications of the 3D burrow systems in artificial cores and consequences on gas diffusion in soil. Soil Biology and Biochemistry, 38 (2), 285-293.

CAPOWIEZ, Y. \& BERARD, A. 2006. Assessment of the effects of imidacloprid on the behavior of two earthworm species (Aporrectodea nocturna and Allolobophora icterica) using 2D terraria. Ecotoxicology and Environment Safety, 64(2), 198-206.

CAPOWIEZ, Y., PIERRET, A. \& MORAN, C.J. 2003. Characterisation of the three-dimensional structure of earthworm burrow systems using image analysis and mathematical morphology. Biology and Fertility of Soils, 38 (5), 301-310.

CARDINALE, B.J., DUFFY, J.E., GONZALEZ, A., HOOPER, D.U., PERRINGS, C., VenAIL, P., NARWANI, A., MACE, G.M., TILMAN, D., WARDLE, D.A. \& KINZIG, A.P. 2012. Biodiversity loss and its impact on humanity. Nature, 486, 59-67.

CHAGNON, M., KREUTZWEISER, D., MITCHELL, E. A. D., MORRISSEY, C. A., NOOME, D. A. \& VAN DER SLUIJS, J. 2015. Risks of large-scale use of systemic insecticides to ecosystem functioning and services. Environmental Science and Pollution Research, 22, 119-134.

CHAUDHARY, P., DUDEJA, S. S. \& KAPOOR, K. K. 2004. Effectivity of host-Rhizobium leguminosarum symbiosis in soils receiving sewage water containing heavy metals. Microbiological Research, 159, 121-127.

CHEN, G., QIN, J., SHI, D., ZHANG, Y. \& JI, W. 2009. Diversity of soil nematodes in areas polluted with heavy metals and polycyclic aromatic hydrocarbons (PAHs) in Lanzhou, China. Environmental Management, 44, 163-172.

CHENG, S. P. 2003. . Effects of heavy metals on plants and resistance mechanisms. Environmental Science and Pollution Research, 10, 256-264.

CHOWDHURY, A., PRADHAN, S., SAHA, M. \& SANYAL, N. 2008. Impact of pesticides on soil microbiological parameters and possible bioremediation strategies. Indian Journal of Microbiology, 48, 114-127.

COLEMAN, D. C., CROSSLEY, D. A. \& HENDRIX, P. F. 2004. Fundamentals of soil ecology, 2nd ed. Elsevier, USA. 408 pp.

COLEMAN, D. C. \& WHITMAN, W.B. 2005. Linking species richness, biodiversity and ecosystem function in soil systems. Pedobiologia, 49, 479-497.

CORTET, J., GOMOT-DE VAUfleRY, A., POINSOT-BALAGUER, N., GOMOT, L., TEXIER, C. \& CLUZEAU, D. 1999. The use of invertebrate soil fauna in monitoring pollutant effects. European Journal of Soil Biology, 35, 115-134.

COSTANTINI, E. A. C., BRANQUINHO, C., NUNES, A., SCHWILCH, G., STAVI, I., VALDECANTOS, A. \& ZUCCA, C. 2016. Soil indicators to assess the effectiveness of restoration strategies in dryland ecosystems. Solid Earth, 7, 397-414.

COSTANZA, R. \& MAGEAU, M., 1999. What is a healthy ecosystem? Aquatic ecology, 33, 105115.

COTRUFO, M. F., VIRZO DE SANTO, A., ALFANI, A., BARTOLO, G. \& DE CRISTOFARO, A. 1995. Effects of urban heavy metal pollution on organic matter decomposition in Quercus ilex L. woods. Environmental Pollution, 88, 81-87. 
CRASWELL, E. T. \& LEFROY, R. D. 2001. The role and function of organic matter in tropical soils. Nutrient Cycling in Agroecosystems, 61, 7-18.

CRAWFORD, J.W., HARRIS, J.A., RITZ, K. \& YOUNG, I.M. 2005. Towards an evolutionary ecology of life in soil. Trends in Ecology and Evolution, 20, 81-87.

CREAMER, R. E., RIMMER, D. L. \& BLACK, H. I. J. 2008. Do elevated soil concentrations of metals affect the diversity and activity of soil invertebrates in the long-term? Soil Use and Management, 24, 37-46.

CROUZET, O., POLY, F., BONNEMOY, F., BRU, D., BATISSON, I., BOHATIER, J., PHILIPPOT, L. \& MALLET, C. 2016. Functional and structural responses of soil $\mathrm{N}$-cycling microbial communities to the herbicide mesotrione: a dose-effect microcosm approach. Environmental Science and Pollution Research, 23, 4207-4217.

CYCÓN, M., BORYMSKI, S., ŻOŁNIERCZYK, B. \& PIOTROWSKA-SEGET, Z. 2016. Variable effects of non-steroidal anti-inflammatory drugs (NSAIDs) on selected biochemical processes mediated by soil microorganisms. Frontiers in Microbiology, 7, 1969.

DANIEL, T. C., MUHAR, A., AMBERGER, A., AZNAR, O., BOYD, J. W., CHAN, K. M. A., COSTANZA, R., ELMQVIST, T., FLINT, C. G., GOBSTER, P. H., GRÊT-REGAMEY, A., LAVE, R., MUHAR, S., PENKER, M., RIBE, R. G., SCHAUPPENLEHNER, T., SIKOR, T., SOLOVY, I., SPIERENBURG, M., TACZANOWSKA, K., TAM, J. \& VON DER DUNK, A. 2012. Contributions of cultural services to the ecosystem services agenda. Proceedings of the National Academy of Sciences, 109, 8812-8819.

DAZY, M., BÉRAUD, E., COTELLE, S., GRÉVILLIOT, F., FÉRARD, J.F. \& MASFARAUD, J.F. 2009. Changes in plant communities along soil pollution gradients: Responses of leaf antioxidant enzyme activities and phytochelatin contents. Chemosphere, 77, 376-383.

DING, K., WU, Q., WEI, H., YANG, W., SÉRÉ, G., WANG, S., ECHEVARRIA, G., TANG, Y., TAO, J., MOREL, J.L. \& QIU, R. 2016. Ecosystem services provided by heavy metalcontaminated soils in China. Journal of Soils and Sediments, in press, doi:10.1007/s11368-016-1547-6.

D'COSTA, V.M., KING, C.E., KALAN, L., MORAR, M., SUNG, W.W., SCHWARZ, C., FROESE, D., ZAZULA, G., CALMELS, F., DEBRUYNE, R. \& GOLDING, G.B. 2011. Antibiotic resistance is ancient. Nature, 477, 457-461.

DE GROOT, R. S., WILSON, M. A. \& BOUMANS, R. M. J. 2002. A typology for the classification, description and valuation of ecosystem functions, goods and services. Ecological Economics, 41, 393-408.

DE RUITER, P.C., NEUTEL, A.M. and MOORE, J.C. 1998. Biodiversity in soil ecosystems: the role of energy flow and community stability. Applied Soil Ecology, 10, 217-228.

DE SILVA, P. M. C. S., PATHIRATNE, A., VAN STRAALEN, N. M. \& VAN GESTEL, C. A. M. 2010. Chlorpyrifos causes decreased organic matter decomposition by suppressing earthworm and termite communities in tropical soil. Environmental Pollution, 158, 3041-3047.

DE VRIES, W., SOlBERG, S., DOBBERTIN, M., STERBA, H., LAUBHANN, D., VAN OIJEN, M., EVANS, C., GUNDERSEN, P., KROS, J., WAMELINK, G. W. W., REINDS, G. J. \& SUTTON, M. A. 2009. The impact of nitrogen deposition on carbon sequestration by European forests and heathlands. Forest Ecology and Management, 258, 1814-1823.

DECAËNS, T. 2010. Macroecological patterns in soil communities. Global Ecology and Biogeography, 19, 287-302.

DECAËNS, T., JIMÉNEZ, J.J., GIOIA, C., MEASEY, G.J. \& LAVELLE, P. 2006. The values of soil animals for conservation biology. European Journal of Soil Biology, 42, S23-S38.

DELCOUR, I., SPANOGHE, P. \& UYTTENDAELE, M. 2015. Literature review: Impact of climate change on pesticide use. Food Research International, 68, 7-15.

DIGEL, C., CURTSDOTTER, A., RIEDE, J., KLARNER, B. \& BROSE, U., 2014. Unravelling the complex structure of forest soil food webs: higher omnivory and more trophic levels. Oikos, 123, 1157-1172. 
DING, K., WU, Q., WEI, H., YANG, W., SÉRÉ, G., WANG, S., ECHEVARRIA, G., TANG, Y., TAO, J, MOREL, J. L. \& QIU, R. In press. Ecosystem services provided by heavy metalcontaminated soils in China. Journal of Soils and Sediments.

DOMINATI, E., PATTERSON, M. \& MACKAY, A. 2010. A framework for classifying and quantifying the natural capital and ecosystem services of soils. Ecological Economics, 69, 1858-1868.

DORAN, J. W., SARRANTONIO, M. \& LIEBIG, M. 1996. Soil health and sustainability. In: SPARKS, D. L. (ed.) Advances in Agronomy, Vol. 56. Academic Press, San Diego, USA. pp. 1-54.

DORAN, J. W. \& ZEISS, M. R. 2000. Soil health and sustainability: managing the biotic component of soil quality. Applied Soil Ecology, 15, 3-11.

DURAN, B. E. L., DUNCAN, D. S., OATES, L. G., KUCHARIK, C. J. \& JACKSON, R. D. 2016. Nitrogen fertilization effects on productivity and nitrogen loss in three grass-based perennial bioenergy cropping systems. PLOS ONE, 11, e0151919.

EC, 2013. Science for Environment Policy In-depth Report: Soil Contamination: Impacts on Human Health. Report produced for the European Commission DG Environment. Science Communication Unit, University of the West of England, Bristol, UK.

EFSA, 2012a. Cadmium dietary exposure in the European population. Scientific report of EFSA. The EFSA Journal 10 (1), 2551 (European Food Safety Authority).

EFSA, 2012b. Scientific opinion on the risk for public health related to the presence of mercury and methylmercury in food. The EFSA Journal 10 (12), 2985 (European Food Safety Authority).

EFSA, 2012c. Lead dietary exposure in the European population. Scientific report of EFSA. The EFSA Journal 10 (7), 2831 (European Food Safety Authority).

ELMQVIST, T., FOLKE, C., NYSTRÖM, M., PETERSON, G., BENGTSSON, J., WALKER, B. \& NORBERG, J. 2003. Response diversity, ecosystem change, and resilience. Frontiers in Ecology and the Environment, 1, 488-494.

ETTEMA, C.H. \& WARDLE, D.A., 2002. Spatial soil ecology. Trends in ecology and evolution, 17, 177-183.

FABER, J.H. \& VAN WENSEM, J. 2012. Elaborations on the use of the ecosystem services concept for application in ecological risk assessment for soils. Science of the total environment, 415, 3-8.

FILIP, Z. 2002. International approach to assessing soil quality by ecologically-related biological parameters. Agriculture, Ecosystems and Environment, 88, 169-174.

FÖRSTER, B., GARCIA, M., FRANCIMARI, O. \& RÖMBKE, J. 2006. Effects of carbendazim and lambda-cyhalothrin on soil invertebrates and leaf litter decomposition in semi-field and field tests under tropical conditions (Amazônia, Brazil). European Journal of Soil Biology, 42, S171-S179.

FÖRSTER, B., VAN GESTEL, C.A.M., KOOLHAAS, J. E., NENTWIG, G., RODRIGUES, J. M. L., SOUSA, J. P., JONES, S. J. \& KNACKER, T. 2004. Ring-testing and field-validation of a terrestrial model ecosystem (TME) - An instrument for testing potentially harmful substances: Effects of carbendazim on organic matter breakdown and soil fauna feeding activity. Ecotoxicology, 13, 129-141.

FOX, J. E., GULLEDGE, J., ENGELHAUPT, E., BUROW, M. E. \& McLACHLAN, J. A. 2007. Pesticides reduce symbiotic efficiency of nitrogen-fixing rhizobia and host plants. Proceedings of the National Academy of Sciences, 104, 10282-10287.

FREITAS, A. C., RODRIGUES, D., ROCHA-SANTOS, T. A. P., GONÇALVES, F., DUARTE, A. C. \& PEREIRA, R. 2014. The impact of uranium mine contamination of soils on plant litter decomposition. Archives of Environmental Contamination and Toxicology, 67, 601-616.

GEISEN, S. 2016. The bacterial-fungal energy channel concept challenged by enormous functional versatility of soil protists. Soil Biology and Biochemistry, 102, 22-25. 
GIELEN, G. J. H. P., CLINTON, P. W., VAN DEN HEUVEL, M. R., KIMBERLEY, M. O., \& GREENFIELD, L. G. 2011. Influence of sewage and pharmaceuticals on soil microbial function. Environmental Toxicology and Chemistry, 30, 1086-1095.

GILLER, P.S., 1996. The diversity of soil communities, the 'poor man's tropical rainforest'. Biodiversity and Conservation, 5, 135-168.

GILLER, K. E., WITTER, E. \& McGRATH, S. P. 2009. Heavy metals and soil microbes. Soil Biology and Biochemistry, 41, 2031-2037.

GIL-SOTRES, F., TRASAR-CEPEDA, C., LEIRÓS, M. C. \& SEOANE, S. 2005. Different approaches to evaluating soil quality using biochemical properties. Soil Biology and Biochemistry, 37, 877-887.

HAANSTRA, L. \& DOELMAN, P. 1991. An ecological dose-response model approach to shortand long-term effects of heavy metals on arylsulphatase activity in soil. Biology and Fertility of Soils, 11, 18-23.

HÅGVAR, S. 1998. The relevance of the Rio-Convention on biodiversity to conserving the biodiversity of soils. Applied Soil Ecology, 9, 1-7.

HAVLICEK, E. \& MITCHELL, E.A., 2014. Soils Supporting Biodiversity. In: DIGHTON, J. \& KRUMINS, J.A. (eds.) Interactions in soil: promoting plant growth. Springer Netherlands. pp 27-58.

HAINES-YOUNG, R. \& POTSCHIN, M. 2011. Common International Classification of Ecosystem Services (CICES): 2011 Update, European Environment Agency, Contract No: EEA/BSS/07/007, November 2011, https://cices.eu/content/uploads/sites/8/2009/11/CICES_Update_Nov2011.pdf.

HEDDE, M., VAN OORT, F. \& LAMY, I. 2012. Functional traits of soil invertebrates as indicators for exposure to soil disturbance. Environmental Pollution, 164, 59-65.

HEDLUND, K., GRIFFITHS, B., CHRISTENSEN, S., SCHEU, S., SETÄLÄ, H., TSCHARNTKE, T. \& VERHOEF, H. 2004. Trophic interactions in changing landscapes: responses of soil food webs. Basic and Applied Ecology, 5, 495-503.

HOLE, D.G., PERKINS, A.J., WILSON, J.D., ALEXANDER, I.H., GRICE, P.V. \& EVANS, A.D. 2005. Does organic farming benefit biodiversity?. Biological conservation, 122, 113-130.

HORWATH, W. 2007. Carbon cycling and formation of soil organic matter. In: PAUL, E. A. (ed.) Soil microbiology, ecology and biochemistry, 3rd ed. Elsevier, USA. pp 303-339.

HUNT, H.W. \& WALL, D.H. 2002. Modelling the effects of loss of soil biodiversity on ecosystem function. Global Change Biology, 8, 33-50.

JEFFERY, S., GARDI, C., JONES, A., MONTANARELLA, L., MARMO, L., MIKO, L., RITZ, K., PERES, G., RÖMBKE, J. \& VAN DER PUTTEN, W. H. 2010. European Atlas of Soil Biodiversity. European Commission, Publications Office of the European Union, Luxembourg. 128 pp.

JOHNSEN, K., JACOBSEN, C. S., TORSVIK, V. \& S $\varnothing$ RENSEN, J. 2001. Pesticide effects on bacterial diversity in agricultural soils - a review. Biology and Fertility of Soils, 33, 443-453.

JONES, L., PROVINS, A., HOLLAND, M., MILLS, G., HAYES, F., EMMETT, B., HALL, J., SHEPPARD, L., SMITH, R., SUTTON, M., HICKS, K., ASHMORE, M., HAINES-YOUNG, R. \& HARPERSIMMODNS, L. 2014. A review and application of the evidence for nitrogen impacts on ecosystem services. Ecosystem Services, 7, 76-88.

JUNG, M.P., KIM, S.T., KIM, H. \& LEE, J.H. 2008. Species diversity and community structure of ground-dwelling spiders in unpolluted and moderately heavy metal-polluted habitats. Water, air, and soil pollution, 195, 15-22.

KANDELER, E., TSCHERKO, D., BRUCE, K. D., STEMMER, M., HOBBS, P. J., BARDGETT, R. D. \& AMELUNG, W. 200. Structure and function of the soil microbial community in microhabitats of a heavy metal polluted soil. Biology and Fertility of Soils, 32, 390-400.

KAYE, J.P. \& HART, S.C. 1997. Competition for nitrogen between plants and soil microorganisms. Trends in Ecology and Evolution, 12, 139-143. 
KAPUSTKA, L. \& MCCORMICK, R. 2015. The rationale for moving beyond monetization in valuing ecosystem services. Integrated Environmental Assessment and Management, 11, 329-336.

KIBBLEWHITE, M. G., RITZ, K. \& SWIFT, M. J. 2008. Soil health in agricultural systems. Philosophical Transactions of the Royal Society B, 363, 685-701.

KOPTSIK, S., KOPTSIK, G., LIVANTSOVA, S., ERUSLANKINA, L., ZHMELKOVA, T. \& VOLOGDINA, Z. 2003. Heavy metals in soils near the nickel smelter: chemistry, spatial variation, and impacts on plant diversity. Journal of Environmental Monitoring, 5, 441-450.

KOSTOV, O. \& VAN CLEEMPUT, O. 2001. Nitrogen transformations in copper-contaminated soils and effects of lime and compost application on soil resiliency. Biology and Fertility of Soils, 33, 10-16.

KOZDRÓJ, J. \& VAN ELSAS, J. D. 2001. Structural diversity of microorganisms in chemically perturbed soil assessed by molecular and cytochemical approaches. Journal of Microbiological Methods, 43, 197-212.

KRUMINS, J.A., KRUMINS, V., FORGOSTON, E., BILLINGS, L., \& VAN DER PUTTEN, W.H. 2015. Herbivory and stoichiometric feedbacks to primary production. PLoS One, 10 (6), e0129775.

KULMATISKI, A., ANDERSON-SMITH, A., BEARD, K.H., DOUCETTE-RIISE, S., MAZZACAVALLO, M., NOLAN, N.E., RAMIREZ, R.A. \& STEVENS, J.R. 2014. Most soil trophic guilds increase plant growth: a meta-analytical review. Oikos, 123, 1409-1419.

LAABS, V., AMELUNG, W., PINTO, A., ALSTAEDT, A. \& ZECH, W. 2000. Leaching and degradation of corn and soybean pesticides in an Oxisol of the Brazilian Cerrados. Chemosphere, 41, 1441-1449.

LAL, R. 2016. Soil health and carbon management. Food and Energy Security, 5, 212-222.

LAVELLE, P. 1996. Diversity of soil fauna and ecosystem function. Biology International, 33, 316.

LAVELLE, P. 2012. Soil as a habitat. In: WALL, D. H., BARDGETT, R. D., BEHAN-PELLETIER, V., HERRICK, J. E., JONES, T. H., RITZ, K., SIX, J., STRONG, D.R. \& VAN DER PUTTEN, W. (eds.) Soil ecology and ecosystem services, Oxford Press University, UK. pp 7-27.

LAVELLE, P., DECAËNS, T., AUBERT, M., BAROT, S., BLOUIN, M., BUREAU, F., MARGERIE, P., MORA, P. \& ROSSI, J.P. 2006. Soil invertebrates and ecosystem services. European Journal of Soil Biology, 42, S3-S15.

LAVELLE, P., LATTAUD, C., TRIGO, D. \& BAROIS, I. 1995. Mutualism and biodiversity in soils. Plant and Soil, 170, 23-33.

LAVELLE, P. \& SPAIN, A.V., 2001. Soil ecology. Springer Science \& Business Media. 654 pp.

LERNER, D. N. \& HARRIS, B. 2009. The relationship between land use and groundwater resources and quality. Land Use Policy, 26S, S265-S273.

LEVEQUE, T., CAPOWIEZ, Y., SCHRECK, E., XIONG, T., FOUCAULT, Y. \& DUMAT, C. 2014. Earthworm bioturbation influences the phytoavailability of metals released by particles in cultivated soils. Environmental Pollution, 191, 199-206.

LI, Y. T., ROULAND, C., BENEDETTI, M., LI, F. B., PANDO, A., LAVELLE, P. \& DAI, J. 2009. Microbial biomass, enzyme and mineralization activity in relation to soil organic $C, N$ and $\mathrm{P}$ turnover influenced by acid metal stress. Soil Biology and Biochemistry, 41, 969977.

LI, X., KAPOOR, V., IMPELLITTERI, C., CHANDRAN, K. \& SANTO DOMINGO, J. W. 2015. Measuring nitrification inhibition by metals in wastewater treatment systems: Current state of science and fundamental research needs. Critical Reviews in Environmental Science and Technology, 0, 1-41.

LIU, Y., LIU, Y., ZHOU, H., LI, L., ZHENG, J., ZHANG, X., ZHENG, J. \& PAN, G. 2016. Abundance, composition and activity of denitrifier communities in metal polluted paddy soils. Scientific Reports, 6, 19086. 
LOMANDER, A. \& JOHANSON, M. B. 2001. Changes in concentration of $\mathrm{Cd}, \mathrm{Zn}, \mathrm{Mn}, \mathrm{Cu}$ and $\mathrm{Pb}$ in spruce needle litter during decomposition. Water, Air and Soil Pollution, 132, 165184.

LOSEY, J. E. \& VAUGHAN, M. 2006. The economic value of ecological services provided by insects. Bioscience, 56, 311-323.

MACK, M. C., SCHUUR,E. A. G., BRET-HARTE, M. S., SHAVER, G. R. \& CHAPIN, F. S. 2004. Ecosystem carbon storage in arctic tundra reduced by long-term nutrient fertilization. Nature, 431, 440-443.

MALTBY, L., DUKE, C. \& VAN WENSEM, J. 2017. Ecosystem services, environmental stressors, and decision making: How far have we got? Integrated Environmental Assessment and Management, 13, 38-40.

MALTBY, L., JACKSON, M., WHALE, G., BROWN, A. R., HAMER, M., SOLGA, A., KABOUW, P., WOODS, R. \& MARSHALL, S. 2017. Is an ecosystem services-based approach developed for setting specific protection goals for plant protection products applicable to other chemicals? Science of the Total Environment, 580, 1222-1236.

MARINARI, S., MANCINELLI, R., CAMPIGLIA, E. \& GREGO, S. 2006. Chemical and biological indicators of soil quality in organic and conventional farming systems in Central Italy. Ecological Indicators, 6, 701-711.

MARSHALL, E. J. P., BROWN, V. K., BOATMAN, N. D., LUTMAN, P. J. W., SQUIRE, G. R. \& WARD, L. K. 2003. The role of weeds in supporting biological diversity within crop fields. Weed Research, 43, 77-89.

MCCANN, K.S. 2000. The diversity-stability debate. Nature, 405, 228-233.

MEGHARAJ, K. V. M., SETHUNATHAN, N. \& NAIDU, R. 2003. Bioavailability and toxicity of cadmium to microorganisms and their activities in soil: a review. Advances in Environmental Research, 8, 121-135.

MICHALKOVÁ, V. \& PEKÁR, S. 2009. How glyphosate altered the behaviour of agrobiont spiders (Araneae: Lycosidae) and beetles (Coleoptera: Carabidae). Biological Control, 51, 444449.

MILLENIUM ECOSYSTEM ASSESSMENT (MA), 2005. Ecosystem and Human Well-Being: Synthesis. Island Press, USA.

MOORE, J.C. 1994. Impact of agricultural practices on soil food web structure: theory and application. Agriculture, Ecosystems and Environment, 51, 239-247.

MOORE, J.C., BERLOW, E.L., COLEMAN, D.C., RUITER, P.C., DONG, Q., HASTINGS, A., JOHNSON, N.C., MCCANN, K.S., MELVILLE, K., MORIN, P.J. \& NADELHOFFER, K. 2004. Detritus, trophic dynamics and biodiversity. Ecology letters, 7, 584-600.

MORETTI, M., DIAS, A.T., BELLO, F., ALTERMATT, F., CHOWN, S.L., AZCÁRATE, F.M., BELL, J.R., FOURNIER, B., HEDDE, M., HORTAL, J. \& IBANEZ, S. 2016. Handbook of protocols for standardized measurement of terrestrial invertebrate functional traits. Functional Ecology, 31, 556-557

MOROŃ, D., GRZEŚ, I.M., SKORKA, P., SZENTGYÖRGYI, H., LASKOWSKI, R., POTTS, S.G. \& WOYCIECHOWSKI, M. 2012. Abundance and diversity of wild bees along gradients of heavy metal pollution. Journal of Applied Ecology, 49, 118-125.

MOSS, B. 2008. Water pollution by agriculture. Philosophical Transactions of the Royal Society $B, 363,659-666$.

MUÑOZ-LEOZ, B., GARBISU, C., CHARCOSSET, J. Y., SÁNCHEZ-PÉREZ, J. M., ANTIGÜEDAD, I. \& RUIZ-ROMERA, E. 2013. Non-target effects of three formulated pesticides on microbially-mediated processes in a clay-loam soil. Science of the Total Environment, 449, 345-354.

NAEEM, S., HAHN, D.R. \& SCHUURMAN, G. 2000. Producer-decomposer co-dependency influences biodiversity effects. Nature, 403, 762-764.

NAGAJYOTI, P. C., LEE, K. D. \& SREEKANTH, T. V. M. 2010. Heavy metals, occurrence and toxicity for plants: a review. Environmental Chemistry Letters, 8, 199-216. 
NAHMANI, J., CAPOWIEZ, Y. \& LAVELLE, P., 2005. Effects of metal pollution on soil macroinvertebrate burrow systems. Biology and fertility of soils, 42, 31-39.

NAHMANI, J. \& LAVELLE, P. 2002. Effects of heavy metal pollution on soil macrofauna in a grassland of Northern France. European Journal of Soil Biology, 38, 297-300.

NAKASHIMA, Y., BIRKETT, M. A., PYE, B. J., PICKETT, J. A. \& POWELL, W. 2004. The role of semiochemicals in the avoidance of the seven-spot ladybird, Coccinella septempunctata, by the aphid parasitoid, Aphidius ervi. Journal of Chemical Ecology, 30, 1103-1116.

NAVEed, M., MOLDRUP, P., ARTHUR, E., HOLMSTRUP, M., NICOLAISEN, M., TULLER, M., HERATH, L., HAMAMOTO, S., KAWAMOTO, K., KOMATSU, T. \& VOGEL, H.J. 2014. Simultaneous loss of soil biodiversity and functions along a copper contamination gradient: when soil goes to sleep. Soil Science Society of America Journal, 78, 12391250.

NEUTEL, A.M., HEESTERBEEK, J.A. \& DE RUITER, P.C. 2002. Stability in real food webs: weak links in long loops. Science, 296, 1120-1123.

NIELSEN, U.N., AYRES, E., WALL, D.H. \& BARDGETT, R.D. 2011. Soil biodiversity and carbon cycling: a review and synthesis of studies examining diversity-function relationships. European Journal of Soil Science, 62, 105-116.

NIEMEYER, J. C., LOLATA, G. B., DE CARVALHO, G. M., DA SILVA, E. M., SOUSA, J. P. \& NOGUEIRA, M. A. 2012a. Microbial indicators of soil health as tools for ecological risk assessment of a metal contaminated site in Brazil. Applied Soil Ecology, 59, 96-105.

NIEMEYER, J. C., NOGUEIRA, M. A., CARVALHO, G. M., COHIN-DE-PINHO, S. J., OUTEIRO, U. S., RODRIGUES, G. G., DA SILVA, E. M. \& SOUSA, J. P. 2012b. Functional and structural parameters to assess the ecological status of a metal contaminated area in the tropics. Ecotoxicology and Environmental Safety, 86, 188-197.

NRC, 2013. Alternatives for managing the nation's complex contaminated groundwater sites. National Academies Press, Washington, USA. 407 pp.

NWUCHE, C. O. \& UGOJI, E. O. 2008. Effects of heavy metal pollution on the soil microbial activity. International Journal of Environmental Science and Technology, 5, 409-414.

O'HALLORAN, K. 2006. Toxicological considerations of contaminants in the terrestrial environment for ecological risk assessment. Human and Ecological Risk Assessment, 12, 74-83.

ORGIAZZI, A., BARDGETT, R.D., BARRIOS, E., BEHAN-PELLETIER, V., BRIONES, M.J., CHOTTE, J.L., DE DEYN, G.B., EGGLETON, P., FIERER, N., FRASER, T. \& HEDLUND, K. 2016. Global soil biodiversity atlas. European Commission, Publications Office of the European Union, Luxembourg. $176 \mathrm{pp}$.

PAOLETTI, M.G. \& PIMENTEL, D. 2000. Environmental risks of pesticides versus genetic engineering for agricultural pest control. Journal of Agricultural and Environmental Ethics, 12, 279-303.

PARKER, S.S. 2010. Buried treasure: soil biodiversity and conservation. Biodiversity and conservation, 19, 3743-3756.

PAUL, E. A. 2007. Soil microbiology, ecology and biochemistry, 3rd ed. Elsevier, USA. 514 pp.

PECK, D. C. 2009. Long-term effects of imidacloprid on the abundance of surface- and soilactive nontarget fauna in turf. Agricultural and Forest Entomology, 11, 405-419.

PEDERSEN, M.B., AXELSEN, J.R.A., STRANDBERG, B., JENSEN, J. \& ATTRILL, M.J. 1999. The impact of a copper gradient on a microarthropod field community. Ecotoxicology, 8, 467-483.

PELOSI, C., BAROT, S., CAPOWIEZ, Y., HEDDE, M. \& VANDENBULCKE, F. 201. Pesticides and earthworms. A review. Agronomy for Sustainable Development, 34, 199-228.

PISA, L. W., AMARAL-ROGERS, V., BELZUNCES, L. P., BONMATIN, J. M., DOWNS, C. A., GOULSON, D., KREUTZWEISER, D. P., KRUPKE, C., LIESS, M., McFIELD, M., MORRISSEY, C. A., NOOME, D. A., SETTELE, J., SIMON-DELSO, N., STARK, J. D., VAN DER SLUIJS, J. P., 
VAN DYCK, H. \& WIEMERS, M. 2015. Effects of neonicotinoids and fipronil on nontarget invertebrates. Environmental Science and Pollution Research, 22, 68-102.

RAMSEY, P.W., RILLIG, M.C., FERIS, K.P., GORDON, N.S., MOORE, J.N., HOLBEN, W.E. \& GANNON, J.E. 2005. Relationship between communities and processes; new insights from a field study of a contaminated ecosystem. Ecology letters, 8, 1201-1210.

RENELLA, G., ORTIGOZA, A. L. R., LANDI, L. \& NANNIPIERI, P. 2013. Additive effects of copper and zinc on cadmium toxicity on phosphatase activities and ATP content of soil as estimated by the ecological dose $\left(E_{50}\right)$. Soil Biology and Biochemistry, 35, 1203-1210.

RIAH, W., LAVAL, K., LAROCHE-AJZENBERG, E., MOUGIN, C., LATOUR, X. \& TRINSOUTROTGATTIN, I. 2014. Effects of pesticides on soil enzymes: a review. Environmental Chemistry Letters, 12, 257-273.

RITZ, K. 2008. Soil as a paradigm of a complex system. In: RAMSDEN, J.J. \& KERVALISHVILI, P.J. (eds.) Complexity and security, IOS Press. pp 103-121.

RÖMBKE, J., BREURE, A.M., MULDER, C. \& RUTGERS, M. 2005. Legislation and ecological quality assessment of soil: implementation of ecological indication systems in Europe. Ecotoxicology and Environmental Safety, 62, 201-210.

RÖMBKE, J., JÄNSCH, S. \& DIDDEN, W. 2005. The use of earthworms in ecological soil classification and assessment concepts. Ecotoxicology and Environmental Safety, 62, 249-265.

SALEMAA, M., VANHA-MAJAMAA, I. \& DEROME, J. 2001. Understorey vegetation along a heavy-metal pollution gradient in SW Finland. Environmental Pollution, 112, 339-350.

SALMINEN, J., SETÄLÄ, H. \& HAIMI, J. 1997. Regulation of decomposer community structure and decomposition processes in herbicide stressed humus soil. Applied Soil Ecology, 6, 265-274.

SÁNCHEZ-BAYO, F. 2011. Impacts of agricultural pesticides on terrestrial ecosystems. In: SÁNCHEZ-BAYO, F., VAN DEN BRINK, P. J. \& MANN, R. M. (ed.) Ecological Impacts of Toxic Chemicals. Bentham Science Publishers Ltd, Australia.

SANTORUFO, L., VAN GESTEL, C.A., ROCCO, A. \& MAISTO, G. 2012. Soil invertebrates as bioindicators of urban soil quality. Environmental Pollution, 161, 57-63.

SCHLOTER, M., DILLY, O. \& MUNCH, J. C. 2003. Indicators for evaluating soil quality. Agriculture, Ecosystems and Environment, 98, 255-262.

SELCK, H., ADAMSEN, P. B., BACKHAUS, T., BANTA, G. T., BRUCE, P. K. H., BURTON Jr., G. A., BUTTS, M .B., BOEGH, E., CLAGUE, J. J., DINH, K. V., DOORN, N., GUNNARSSON, J. S., HAUGGAARD-NIELSEN, H., HAZLERIGG, C., HUNKA, A. D., JENSEN, J., LIN, Y., LOUREIRO, S., MIRAGLIA, S., MUNNS Jr., W. R., NADIM, F., PALMQVIST, A., RÄMÖ. R. A., SEABY, L. P., SYBERG, K., TANGAA, S. R., THIT, A., WINDFELD, R., ZALEWSKI, M. \& CHAPMAN, P. $M .2017$. Assessing and managing multiple risks in a changing world - The Roskilde recommendations. Environmental Toxicology and Chemistry, 36, 7-16.

SCHAEFFER, A., VAN DEN BRINK, P.J., HEIMBACH, F., HOY, S.P., DE JONG, F.M., RÖMBKE, J., ROß-NICKOLL, M. \& SOUSA, J.P. 2010. Semi-field methods for the environmental risk assessment of pesticides in soil. CRC Press, USA. 103 pp.

SCHEU, S. 2002. The soil food web: structure and perspectives. European Journal of Soil Biology, 38, 11-20.

SCHEU, S. \& FALCA, M. 2000. The soil food web of two beech forests (Fagus sylvatica) of contrasting humus type: stable isotope analysis of a macro-and a mesofaunadominated community. Oecologia, 123, 285-296.

SCHWEITZER, J.A., MADRITCH, M.D., FELKER-QUINN, E. \& BAILEY, J.K. 2013. From genes to ecosystems: plant genetics as a link between above-and belowground processes. In: WALL, D. H., BARDGETT, R. D., BEHAN-PELLETIER, V., HERRICK, J. E., JONES, T. H., RITZ, K., SIX, J., STRONG, D.R. \& VAN DER PUTTEN, W. (eds.) Soil ecology and ecosystem services, Oxford Press University, UK. pp 82-97. 
SILVERTOWN, J. 2015. Have ecosystem services been oversold? Trends in Ecology and Evolution, 30, 641-648.

SMITH, P., COTRUFO, M. F., RUMPEL, C., PAUSTIAN, K., KUIKMAN, P. J., ELLIOTT, J. A., McDOWELL, R., GRIFFITHS, R. I., ASAKAWA, S., BUSTAMANTE, M., HOUSE, J. I., SOBOCKÁ, J., HARPER, R., PAN, G., WEST, P. C., GERBER, J. S., CLARK, J. M., ADHYA, T., SCHOLES, R. J. \& SCHOLES, M.C. 2015. Biogeochemical cycles and biodiversity as key drivers of ecosystem services provided by soils. Soil, 1, 665-685.

SNYDER, B.A. \& HENDRIX, P.F. 2008. Current and potential roles of soil macroinvertebrates (earthworms, millipedes, and isopods) in ecological restoration. Restoration Ecology, $16,629-636$.

SOBOLEV, D. \& BEGONIA, M. F. T. 2008. Effects of heavy metal contamination upon soil microbes: lead-induced changes in general and denitrifying microbial communities as evidenced by molecular markers. International Journal of Environmental Research and Public Health, 5, 450-456.

STANKOVIC, S., KALABA, P. \& STANKOVIC, A. R. 2014. Biota as toxic metal indicators. Environmental Chemistry Letters, 12, 63-84.

STOCKMANN, U., ADAMS, M. A. CRAWFORD, J. W., FIELD, D. J., HENAKAARCHCHI, N., JENKINS, M., MINASNY, B., McBRATNEY, A. B., DE REMY DE COURCELLES, V., SINGH, K., WHEELER, I., ABBOTT, L., ANGERS, D. A., BALDOCK, J., BIRD, M., BROOKES, P. C., CHENU, C., JASTROW, J.D., LAL, R., LEHMANN, J., O'DONNELL, A. G., PARTON, W. J., WHITEHEAD, D. \& ZIMMERMANN, M. 2013. The knowns, known unknowns and unknowns of sequestration of soil organic carbon. Agriculture, Ecosystems and Environment, 164, 80-99.

STONE, D., RITZ, K., GRIFFITHS, B. G., ORGIAZZI, A. \& CREAMER, R. E. 2016. Selection of biological indicators appropriate for European soil monitoring. Applied Soil Ecology, 97, 12-22.

TAN, K. H. 1994. Environmental soil science, 2nd ed. Dekker, USA.

TEEB, 2009. The economics of ecosystems and biodiversity for national and international policy makers - summary: responding to the value of nature.

THIELE-BRUHN, S., BLOEM, J., DE VRIES, F.T., KALBITZ, K. \& WAGG, C. 2012. Linking soil biodiversity and agricultural soil management. Current Opinion in Environmental Sustainability, 4, 523-528.

THOMPSON, R.M., BROSE, U., DUNNE, J.A., HALL, R.O., HLADYZ, S., KITCHING, R.L., MARTINEZ, N.D., RANTALA, H., ROMANUK, T.N., STOUFFER, D.B. \& TYLIANAKIS, J.M. 2012. Food webs: reconciling the structure and function of biodiversity. Trends in ecology and evolution, 27, 689-697.

TIAN, D., WANG, H., SUN, J. \& NIU, S. 2016. Global evidence on nitrogen saturation of terrestrial ecosystem net primary productivity. Environmental Research Letters, 11, 024012.

TURBÉ, A., DE TONI, A., BENITO, P., LAVELLE, P., LAVELLE, P., CAMACHO, N.R., VAN DER PUTTEN, W.H., LABOUZE, E. \& MUDGAL, S. 2010. Soil biodiversity: functions, threats and tools for policy makers. Bio Intelligence Service, IRD and NIOO. Report for European Commission (DG Environment). 250 pp.

UDEIGWE, T. K., TEBOH, J. M., EZE, P. N., STIETIVA, M. H., KUMAR, V., HENDRIX, J., MASCAGNI, H. J., YING, T. \& KANDAKJI, T. Y. 2015. Implications of leading crop production practices on environmental quality and human health. Journal of Environmental Management, 151, 267-279.

VAN DER PUTTEN, W.H., DE RUITER, P.C., BEZEMER, T.M., HARVEY, J.A., WASSEN, M. \& WOLTERS, V., 2004. Trophic interactions in a changing world. Basic and Applied Ecology, 5, 487-494.

VAN STRAALEN, N.M. 2002. Assessment of soil contamination-a functional perspective. Biodegradation, 13, 41-52. 
VAN STRAALEN, N. M. 2004. The use of soil invertebrates in ecological surveys of contaminated soils. In: Doelman, P. \& Eijsacker, H. J. P. (ed.) Vital Soil - Function, Value and Properties. Elsevier, The Netherlands. pp 159-195.

VAN STRAALEN, N.M., BUTOVSKY, R.O., POKARZHEVSKII, A.D., ZAITSEV, A.S. \& VERHOEF, S.C. 2001. Metal concentrations in soil and invertebrates in the vicinity of a metallurgical factory near Tula (Russia). Pedobiologia, 45, 451-466.

VARGAS ROJAS, R., ACHOURI, M., MAROULIS, J. \& CAON, L. 2016. Healthy soils: a prerequisite for sustainable food security. Environmental Earth Sciences, 75, 180.

WALL, D. H., BARDGETT, R. D., BEHAN-PELLETIER, V., HERRICK, J. E., JONES, T. H., RITZ, K., SIX, J., STRONG, D.R. \& VAN DER PUTTEN, W. 2012. Soil ecology and ecosystem services. Oxford Press University, UK. 406 pp.

WALL, D.H., BARDGETT, R.D. \& KELLY, E., 2010. Biodiversity in the dark. Nature Geoscience, 3, 297-298.

WALL, D. H., NIELSEN, U. N. \& SIX, J. 2015. Soil biodiversity and human health. Nature, 528, 6976.

WANG, Y. P., SHI, J. Y., WANG, H., LIN, Q., CHEN, X. C. \& CHEN, Y. X. 2007. The influence of soil heavy metals pollution on soil microbial biomass, enzyme activity, and community composition near a copper smelter. Ecotoxicology and Environmental Safety, 67, 7581.

WARDLE, D.A., 2006. The influence of biotic interactions on soil biodiversity. Ecology letters, 9, 870-886.

WARDLE, D.A., HUSTON, M.A., GRIME, J.P., BERENDSE, F., GARNIER, E., LAUENROTH, W.K., SETÄLÄ, H. \& WILSON, S.D. 2000. Biodiversity and ecosystem function: an issue in ecology. Bulletin of the Ecological Society of America, 81, 235-239.

WARDLE, D. A., NICHOLSON, K. S. \& RAHMAN, A. 1994. Influence of herbicide applications on the decomposition, microbial biomass, and microbial activity of pasture shoot and root litter. New Zealand Journal of Agricultural Research, 37, 29-39.

WOLTERS, V., SILVER, W.L., BIGNELL, D.E., COLEMAN, D.C., LAVELLE, P., VAN DER PUTTEN, W.H., DE RUITER, P., RUSEK, J., WALL, D.H., WARDLE, D.A. \& BRUSSARD, L. 2000. Effects of Global Changes on Above-and Belowground Biodiversity in Terrestrial Ecosystems: Implications for Ecosystem Functioning. Bioscience, 50, 1089-1098.

WORM, B. \& DUFFY, J.E., 2003. Biodiversity, productivity and stability in real food webs. Trends in Ecology and Evolution, 18, 628-632.

WUANA, R.A. \& OKIEIMEN, F.E. 2011. Heavy metals in contaminated soils: a review of sources, chemistry, risks and best available strategies for remediation, International Scholarly Research Network, ISRN Ecol., Article ID: 402647, 20 pp.

WURST, S., DE DEYN, G. B. \& ORWIN, K. 2012. Soil Biodiversity and Functions. In: WALL, D. H., BARDGETT, R. D., BEHAN-PELLETIER, V., HERRICK, J. E., JONES, T. H., RITZ, K., SIX, J., STRONG, D.R. \& VAN DER PUTTEN, W. (eds.) Soil ecology and ecosystem services, Oxford Press University, UK. pp 28-44.

YANG, Y., CHEN, Y. X., TIAN, G. M., \& ZHANG, Z. J. 2007. Dynamics of microbial activity related to $\mathrm{N}$ cycling in Cd-contaminated soil during growth of soybean. Pedosphere, 17, 383388.

YAN, J., QUAN, G. \& DING, C. 2013. Effects of the combined pollution of lead and cadmium on soil urease activity and nitrification. Procedia Environmental Sciences, 18, 78-83.

YANG, R.Y., TANG, J.J., YANG, Y.S. \& CHEN, X. 2007. Invasive and non-invasive plants differ in response to soil heavy metal lead contamination. Botanical Studies, 48, 453-458.

YOUNG, I.M., BLANCHART, E., CHENU, C., DANGERFIELD, M., FRAGOSO, C. GRIMALDI, M., INGRAM, J. \& MONROZIER, L. J. 1998. The interaction of soil biota and soil structure under global change. Global Change Biology, 4, 703-712.

YU, C., LIN, R., FU, M., ZHOU, Y., ZONG, F., JIANG, H., LV, N., PIAO, X., ZHANG, J., LIU, Y. \& BROCK, T. C. M. 2014. Impact of imidacloprid on life-cycle development of Coccinella 
septempunctata in laboratory microcosms. Ecotoxicology and Environmental Safety, 110, 168-173.

ZAITSEV, A. S. \& VAN STRAALEN, N. M. 2001. Species diversity and metal accumulation in oribatid mites (Acari, Oribatida) of forests affected by a metallurgical plant. Pedobiologia, 45, 467-479.

ZALLER, J. G., KÖNIG, N., TIEFENBACHER, A., MURAOKA, Y., QUERNER, P., RATZENBÖCK, A., BONKOWSKI, M. \& KOLLER, R. 2016. Pesticide seed dressings can affect the activity of various soil organisms and reduce decomposition of plant material. BMC Ecolology, 16:37.

ZHANG, F. P., LI, C. F., TONG, L. G., YUE, L. X., LI, P., CIREN, Y. J. \& CAO, C. C. 2010. Response of microbial characteristics to heavy metal pollution of mining soils in central Tibet, China. Applied Soil Ecology, 45, 144-151.

ZHANG, M., XU, Z., TENG, Y., CHRISTIE, P., WANG, J., REN, W., LUO, Y. \& LI, Z. 2016. Non-target effects of repeated chlorothalonil application on soil nitrogen cycling: The key functional gene study. Science of the Total Environment, 543, 636-643.

ZHOU, T., LI, L., ZHANG, X., ZHENG, J., ZHENG, J., JOSEPH, S. \& PAN, G. 2016. Changes in organic carbon and nitrogen in soil with metal pollution by $\mathrm{Cd}, \mathrm{Cu}, \mathrm{Pb}$ and $\mathrm{Zn}$ : a metaanalysis. European Journal of Soil Science, 67, 237-246.

ZHOU, T., PAN, G., LI, L., ZHANG, X., ZHENG, J., ZHENG, J. \& CHANG, A. 2014. Changes in greenhouse gas evolution in heavy metal polluted paddy soils with rice straw return: $A$ laboratory incubation study. European Journal of Soil Biology, 63, 1-6.

\section{Figure captions}

Figure 1. Relationships between soil ecosystem functions and services and relevant indicators/endpoints.

Figure 2. Soil organic matter turnover. 


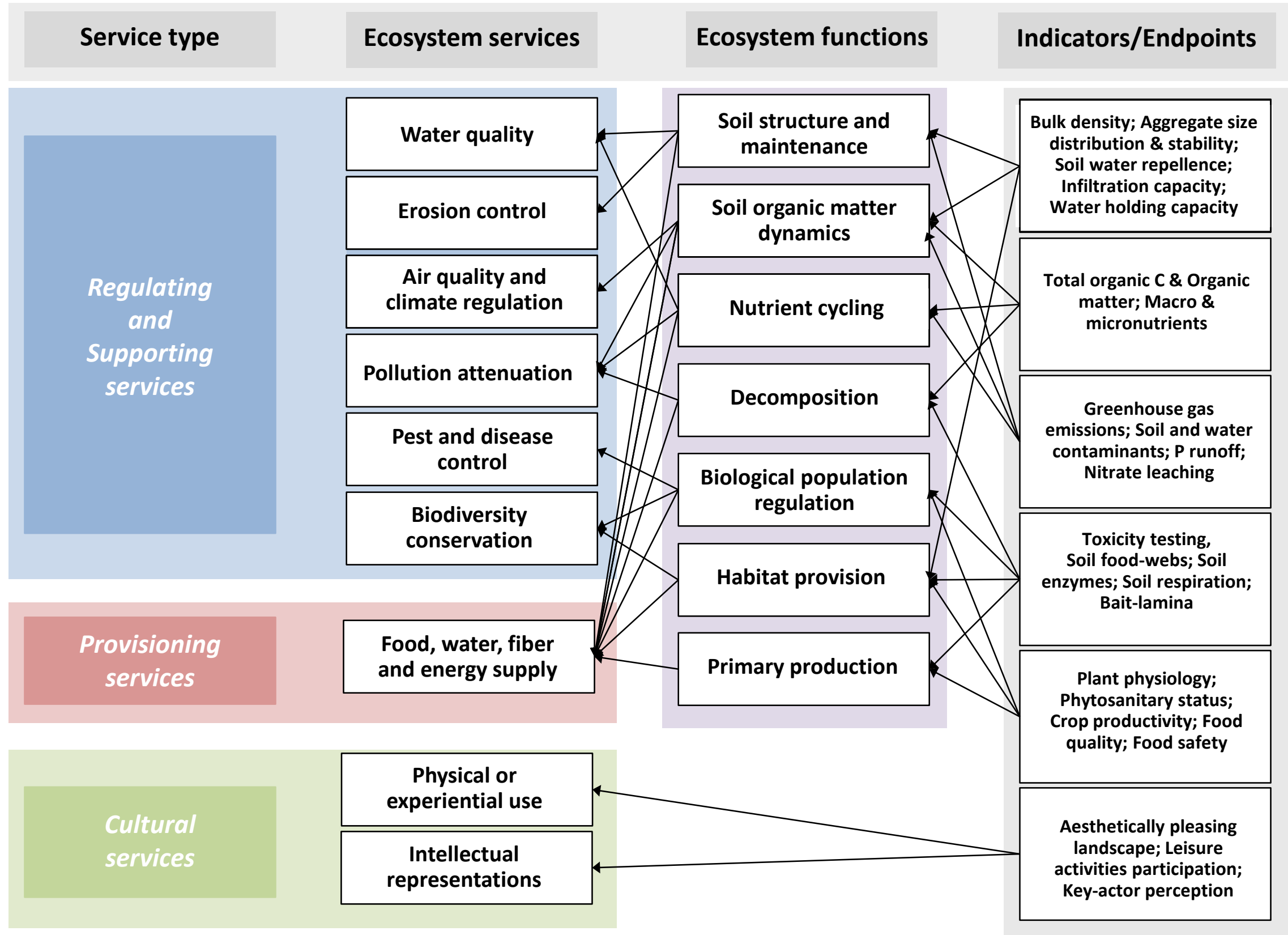


Primary producers

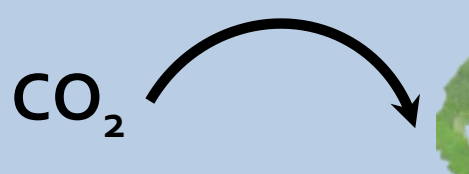

(plants)

Soil invertebrates

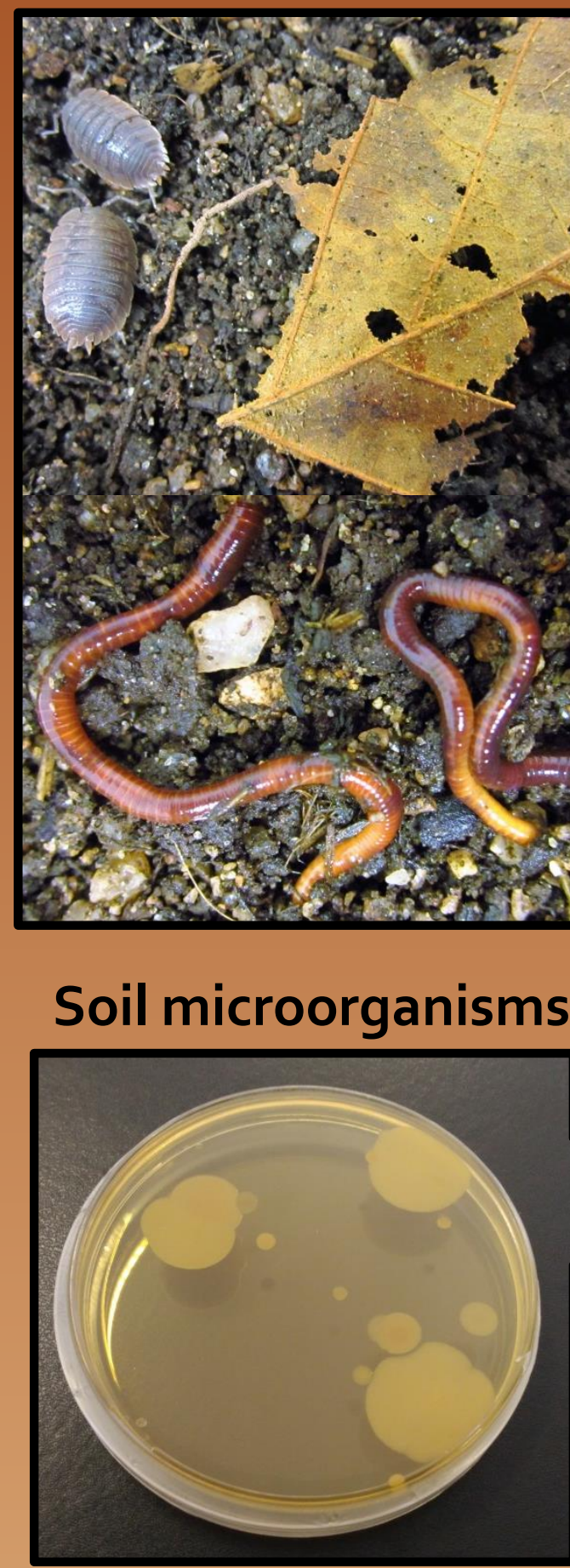

Biological remains

(e.g., leaves, old roots, dead tissues)

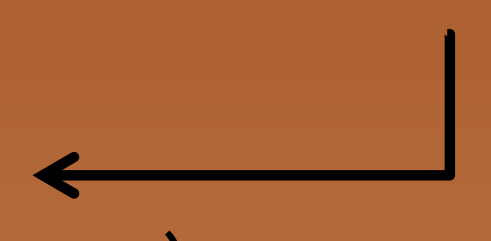

Soluble nutrients

(e.g., $\mathrm{NO}_{3}^{-}, \mathrm{PO}_{4}{ }^{-}$) (e.g., $\mathrm{CO}_{2}, \mathrm{~N}_{2} \mathrm{O}$ )
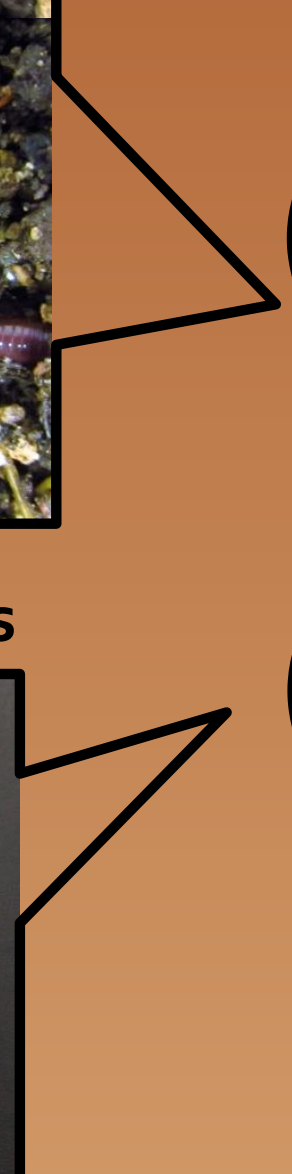

Chemical degradation

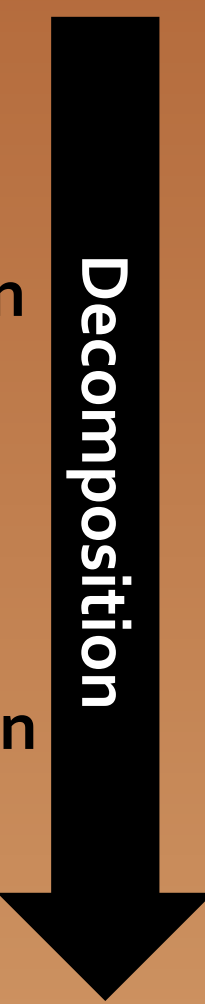

Simpler organic compounds

(e.g., carbohydrates, proteins)

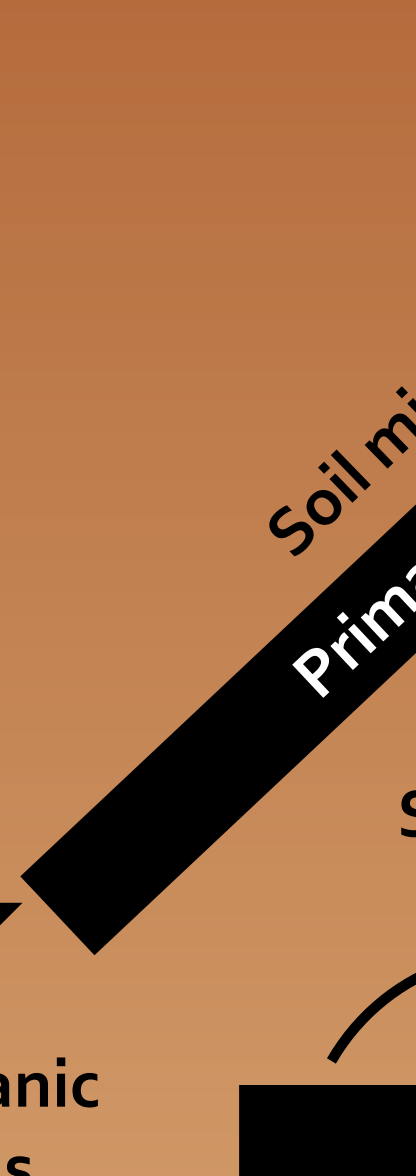

Soil microorganisms/ chemical reactions
Gases 
Table 1. Examples of physical, chemical and biological indicators used to assess/monitor soil quality and health.

\begin{tabular}{|c|c|c|}
\hline Physical indicators & Chemical indicators & Biological indicators \\
\hline $\begin{array}{ll}\text { - } & \text { Bulk density } \\
\text { - } & \text { Aggregate stability } \\
\text { - } & \text { Water holding capacity } \\
\text { - } & \text { Infiltration capacity } \\
\text { - } & \text { Topsoil depth } \\
\text { - } & \text { Slaking } \\
\text { - } & \text { Soil crusts } \\
\text { - } & \text { Soil structure } \\
\text { - } & \text { Macropores }\end{array}$ & $\begin{array}{ll}\text { - } & \mathrm{pH} \\
\text { - } & \text { Electrical conductivity } \\
\text { - } & \text { Cation exchange capacity } \\
\text { - } & \text { Total organic carbon } \\
\text { - } & \text { Total nitrogen } \\
\text { - } & \mathrm{C}: \mathrm{N} \text { ratio } \\
\text { - } & \text { Available nutrients } \\
& \left(\text { e.g. } \mathrm{NH}_{4}^{+}, \mathrm{NO}_{3}^{-}, \mathrm{PO}_{4}{ }^{3-}\right) \\
\text { - } & \text { Available contaminants }\end{array}$ & $\begin{array}{l}\text { - } \text { Soil respiration } \\
\text { - } \text { Microbial biomass } \\
\text { - } \text { Enzymes (e.g. dehydrogenase, } \beta \text {-glucosidase, } \\
\text { - } \text { phosphatase, arylsulfatase, urease) } \\
\text { - } \text { Potentially mineralizable nitrogen } \\
\text { - } \text { Microfauna abundance and richness } \\
\text { (e.g. nematodes) } \\
\text { - Mesofauna abundance and richness } \\
\text { - (e.g. collembola, mites) } \\
\text { Macrofauna abundance and richness } \\
\text { (e.g. earthworms, termites) } \\
\text { - Metabolic quotient - qCO }{ }_{2} \\
\text { - Litter decomposition } \\
\text { (e.g. litter bags, tea bags) } \\
\text { - Fauna feeding activity } \\
\text { (e.g. bait-lamina test) } \\
\text { - Food webs (e.g. bioaccumulation, } \\
\text { biomagnification) }\end{array}$ \\
\hline
\end{tabular}

